\title{
Well Installation and Sampling Report for Monitoring Wells TCM6 TCM7, and TNX 28D - 40D and GeoSiphon Cell TGSC-2
}

by

R. L. Nichols

Westinghouse Savannah River Company

Savannah River Site

Aiken, South Carolina 29808

K. L. Dixon

J. V. Noonkester

DOE Contract No. DE-AC09-96SR18500

This paper was prepared in connection with work done under the above contract number with the U. S.

Department of Energy. By acceptance of this paper, the publisher and/or recipient acknowledges the U. S. Government's right to retain a nonexclusive, royalty-free license in and to any copyright covering this paper, along with the right to reproduce and to authorize others to reproduce all or part of the copyrighted paper. 


\title{
Well Installation and Sampling Report
}

\author{
for Monitoring Wells \\ TCM6, TCM7 and TNX 28D - 40D \\ and GeoSiphon Cell TGSC-2(U)
}

Westinghouse Savannah River Company

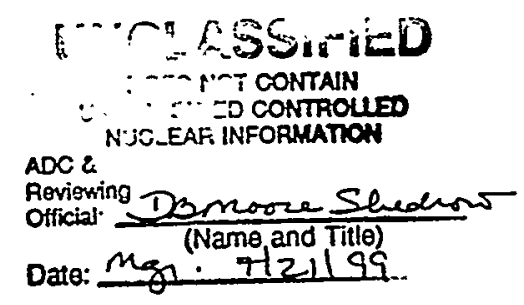

Aiken, SC

Prepared for the U. S Department of Energy under contract no. DE-AC09-96SR18500 


\title{
Well Installation and Sampling Report for Monitoring Wells
}

\author{
TCM6, TCM7 and TNX 28D - 40D \\ and GeoSiphon Cell TGSC-2(U)
}

March 1999

R. L. Nichols

K. L. Dixon

J. V. Noonkester

Westinghouse Savannah River Company

Savannah River Site

Aiken, SC

Prepared for the U. S Department of Energy under contract no. DE-AC09-96SR18500 


\section{DISCLAIMER}

This report was prepared as an account of work sponsored by an agency of the United States Government. Neither the United. States Government nor any agency thereof, nor any of their employees, makes any warranty, express or implied, or assumes any legal liability or responsibility for the accuracy, completeness, or usefulness of any information, apparatus, product, or process disclosed, or represents that its use would not infringe privately owned rights. Reference herein to any specific commercial product, process, or service by trade name, trademark, manufacturer, or otherwise does not necessarily constitute or imply its endorsement, recommendation, or favoring by the United States Government or any agency thereof. The views and opinions of authors expressed herein do not necessarily state or reflect those of the United States Government or any agency thereof.

This report has been reproduced directly from the best available copy.

Available to DOE and DOE contractors from the Office of Scientific and Technical Information, P.O. Box 62, Oak Ridge, TN 37831; prices available from (615) 576-8401.

Available to the public from the National Technical Information Service, U.S. Department of Commerce; 5285 Port Royal Road, Springfield, VA 22161. 


\section{Table of Contents}

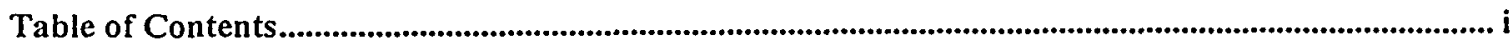

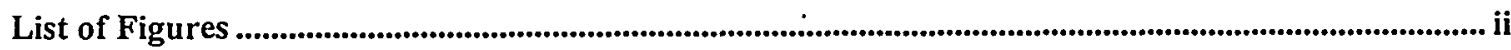

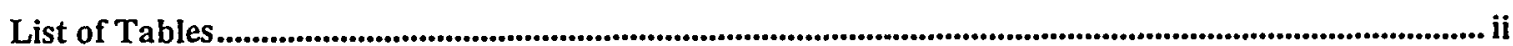

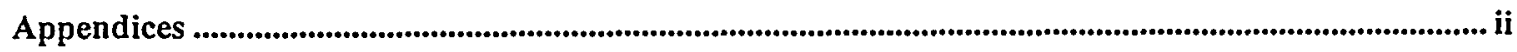

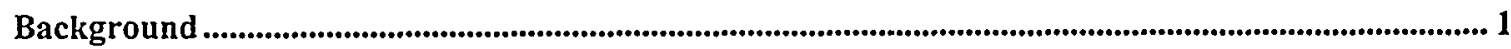

Monitoring Well and Piezometer Installation ..............................................................................

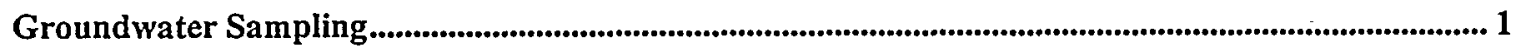

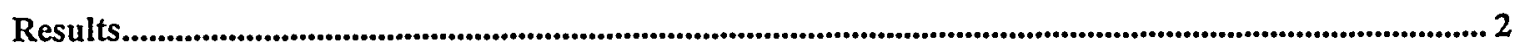

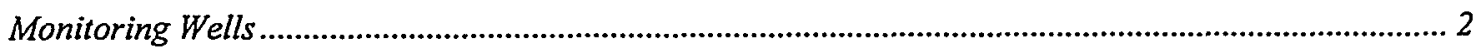

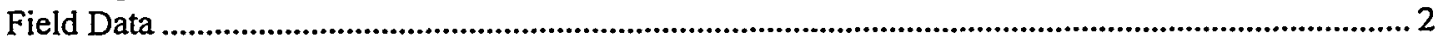

Chlorinated Volatile Organic Compounds ....................................................................................2

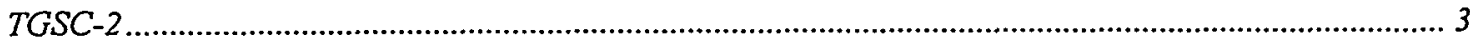

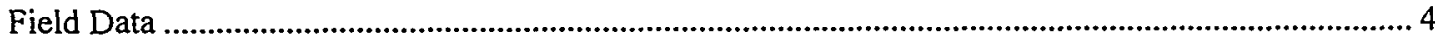

Chlorinated Volatile Organic Compounds .....................................................................................4

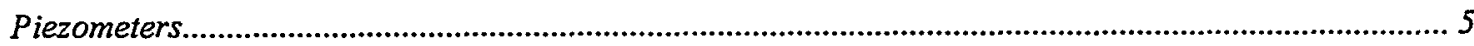

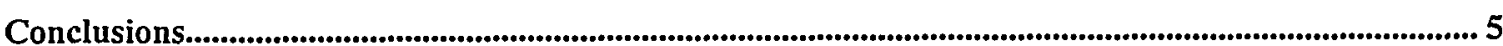

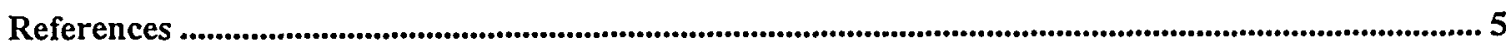




\section{DISCLAIMER}

Portions of this document may be illegible in electronic image products. Images are produced from the best available original document. 


\section{List of Figures}

Figure 1. Map of monitoring wells in the TNX swamp ...............................................................................7 7

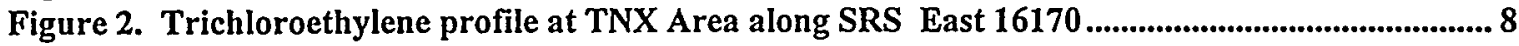

Figure 3. Vertical placement of monitoring well screens in the TNX swamp..........................................9

\section{List of Tables}

Table 1. Well construction details for new monitoring wells and GeoSiphon cell TGSC-2.................. 2 Table 2. Average Trichloroethylene (TCE) concentrations in samples collected from December 1998

to March 1999 for this study...................................................................................................................... 3

Table 3. Field data for GeoSiphon Cell TGSC-2. ................................................................................. 4

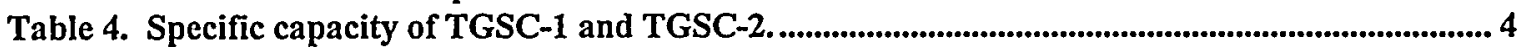

Table 5. Water elevation $(\mathrm{ft}, \mathrm{msl})$ in new piezometers............................................................................ 5

\section{Appendices}

Appendix A ...........................................................................................................Well Construction Diagrams

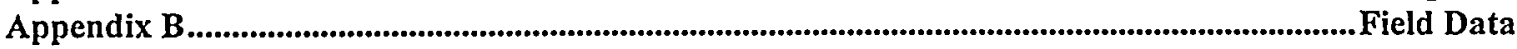
Appendix C...................................... Results from Analysis of Chlorinated Volatile Organic Compounds 


\section{Background}

The shallow groundwater and sediments beneath the TNX Area are contaminated with both dissolved and residual chlorinated volatile organic compounds (CVOCs) such as trichloroethylene (TCE), carbon tetrachloride and perchloroethylene (PCE). The Savannah River Technology Center (SRTC) is studying a new technology for remediating CVOCs known as GeoSiphon. The GeoSiphon Cell is a large diameter well that uses granular cast iron for filter pack material and is operated by inducing a siphon to draw contaminated groundwater through the iron filter pack. As groundwater flows through the granular cast iron CVOCs are reduced to ethane, ethene, methane, and chloride ions. Previous laboratory and field studies (ETI, 1996, and Phifer et. al., 1998) conducted by SRTC have shown that granular cast iron is capable of reducing the concentration of CVOC's in the groundwater to below Maximum Contaminant Levels (MCLs) 40CFR, 1989.

This report documents the installation and sampling of ten monitoring wells that were installed to assist in the characterization of the north - south extent of CVOC contamination in the TNX swamp. In addition, three piezometers were installed to monitor groundwater levels around a surface depression north of TNX and two monitoring wells were installed in the vicinity of GeoSiphon Cell TGSC-2.

\section{Monitoring Well and Piezometer Installation}

A well driller licensed in the State of South Carolina installed the monitoring wells and piezometers using an auger. Two-inch diameter Schedule $40 \mathrm{PVC}$ casing and slotted well screen were used to construct each well. An artificial filter pack of sand was tremied into the hole around the well screen and then bentonite pellets were used to complete the well to the surface. Table 1 contains the well construction details for each well. After the wells and piezometers were installed they were developed until the water was clear (< 15 NTU) using air pumping and a submersible electric pump. Well construction diagrams for each of the wells are included in Appendix A.

The new monitoring wells, TNX28D - TNX 37D, installed for this study have well screens that are 10 feet long and extend from 5 to 15 feet below the ground surface. This screen length and location is based on the results of previous studies by Phifer et al. (1998) and Nichols et al. (1998) that show that CVOC contamination is in the upper 15 feet of sediments in the TNX floodplain. Monitoring wells were screened only in the contaminated zone where GeoSiphon cells may be constructed to produce samples that best represent groundwater that would be treated by the proposed GeoSiphon cells. Wells TCM6 and TCM7 have screens 15 feet long and were installed to monitor water levels in a test with multiple GeoSiphon cells, TGSC-1 and TGSC-2. Three piezometers, TNX38D - TNX40D, were installed with screens 7.5 feet long to monitor the water levels around the surface depression north of TNX.

\section{Groundwater Sampling}

Three rounds of groundwater samples were collected from each of the new monitoring wells and several existing monitoring wells in the vicinity of the proposed line of GeoSiphon cells using low flow rate (micro) purge and sampling techniques. Figure 1 is a map showing the location of monitoring wells used in this study. Each well was purged until field parameters $\mathrm{pH}$ and specific conductivity had stabilized. Field parameters were measured using a YSI portable flow through cell equipped with probes for measuring $\mathrm{pH}$, specific conductivity, dissolved oxygen, redox potential, and temperature. After purging was complete, water samples were collected for CVOC analysis in $20 \mathrm{~mL}$ glass vials and were sealed. The sealed samples were analyzed for cis-1,2-dichloroethylene (CDCE), chloroform ( $\mathrm{CHCl3}), 1,1,1-$ trochloroethane (TCA), carbon tetrachloride (CC14), trichloroethylene (TCE), and tetrachloroethylene (PCE), using a gas chromatograph equipped with a flame ionization detector and an electron capture detector using SRTC procedure WSRC-L14.1 2-76 Rev. 1. The SRTC procedure is a modified version of the EPA, 1995 procedure for Headspace Analysis \# 5021. 
Table 1. Well construction details for new monitoring wells and GeoSiphon cell TGSC-2.

\begin{tabular}{cccccccccc}
\hline & \multicolumn{7}{c}{ SRS Coordinants (ft) } & \multicolumn{7}{c}{ Elevation (ft, msl) } & & \\
\cline { 2 - 8 } Location & East & North & Surface & T.O.Csg & Top SZ & Bot SZ & Type & Materials \\
\hline TCM-6 & 16172.78 & 71106.77 & 97.54 & 100.09 & 94.37 & 79.37 & monitoring & 2" PVC \\
TCM-7 & 16183.57 & 71095.49 & 97.61 & 100.04 & 94.59 & 79.59 & monitoring & 2" PVC \\
TNX-28D & 16158.33 & 71325.76 & 97.44 & 99.81 & 92.614 & 82.614 & monitoring & 2" PVC \\
TNX-29D & 16149.5 & 71264.5 & 97.67 & 100.23 & 93.126 & 83.126 & monitoring & 2" PVC \\
TNX-30D & 16167.66 & 70930.56 & 100.33 & 103.05 & 95.648 & 85.648 & monitoring & 2" PVC \\
TNX-31D & 16168.91 & 70844.73 & 100.23 & 102.89 & 95.493 & 85.493 & monitoring & 2" PVC \\
TNX-32D & 16156.38 & 70735.08 & 98.54 & 101.16 & 94.056 & 84.056 & monitoring & 2" PVC \\
TNX-33D & 16162.44 & 70658.51 & 98.29 & 100.86 & 93.764 & 83.764 & monitoring & 2" PVC \\
TNX-34D & 16200.12 & 70535.81 & 97.52 & 100.19 & 93.291 & 83.291 & monitoring & 2" PVC \\
TNX-35D & 16216.22 & 70464.96 & 97.39 & 99.95 & 92.446 & 82.446 & Monitoring & 2" PVC \\
TNX-36D & 16258.79 & 70341.44 & 97.35 & 99.86 & 92.657 & 82.657 & Monitoring & 2" PVC \\
TNX-37D & 16272.72 & 70270.6 & 98.24 & 100.72 & 93.521 & 83.521 & Monitoring & 2" PVC \\
TNX-38D & 16692.09 & 72082.37 & 115.58 & 117.37 & 114.82 & 107.32 & Piezometer & 2" PVC \\
TNX-39D & 16905.55 & 71956.4 & 118.86 & 121.41 & 116.41 & 108.91 & Piezometer & 2" PVC \\
TNX-40D & 16854.17 & 72274.65 & 115.21 & 117.65 & 111.25 & 101.25 & Piezometer & 2" PVC \\
TGSC-2 & 16172.48 & 71096.41 & 97.56 & 98.46 & 92.56 & 77.56 & GeoSiphon & 12" \\
& & & & & & & Cell & Stainless \\
& & & & & & & & Steel \\
\hline
\end{tabular}

\section{Results}

\section{Monitoring Wells}

\section{Field Data}

The $\mathrm{pH}$ ranged from 4.36 to $6.06 \mathrm{pH}$ units and specific conductivity ranged 0.032 to $0.216 \mathrm{mS} / \mathrm{cm}$ which is typical for groundwater in shallow aquifers at SRS. These results suggest that the wells were installed properly, do not have any bentonite contamination in the screen zone, and should provide representative high quality samples of groundwater. All of the field data is included in Appendix B.

\section{Chlorinated Volatile Organic Compounds}

Trichloroethylene (TCE) and carbon tetrachloride are the most prevalent CVOCs in the water samples collected in this study. Wells located toward the north and south end of the line wells that were sampled have the lowest concentrations and wells near the center of the line have the highest concentrations. Figure 2 shows the profile of TCE along the line of wells used in the study. Samples collected from wells with screens that terminate above 79 feet above msl generally have higher TCE concentrations than wells that have screens that terminate below 79 feet $\mathrm{msl}$ (Figure 2, Table 2). The lower concentrations in wells with longer screens is due to mixing of shallow contaminated water with deeper clean water in the well and is consistent with the findings in Phifer et al. (1998) and Nichols et al. (1998) that show the CVOC concentration is confined to a relatively shallow thin zone beneath the TNX floodplain. Figure 3 shows the location of well screens and average water level elevation for each well used in the study. While the newer wells show a more refined delineation of the extent of groundwater contamination, the original wells (TNX 8D to 12D) provide useful data for evaluating the overall nature of groundwater contamination in the TNX swamp and locating the GeoSiphon cells. The existing GeoSiphon cells are capable of remediating a significant portion of the contaminated groundwater entering the TNX swamp as is illustrated in Figure 2. 
Table 2. Average Trichloroethylene (TCE) concentrations in samples collected from December 1998 to March 1999 for this study.

\begin{tabular}{|c|c|c|c|}
\hline \multicolumn{2}{|c|}{$\begin{array}{l}\text { Wells with screens that } \\
\text { terminate below } 79 \mathrm{ft}, \\
\text { msl }\end{array}$} & \multicolumn{2}{|c|}{$\begin{array}{c}\text { Wells with screens that } \\
\text { terminate above } 79 \mathrm{ft} \text {, } \\
\text { msl }\end{array}$} \\
\hline Well & $\begin{array}{c}\text { Avg TCE } \\
\text { (ug/L) }\end{array}$ & Well & $\begin{array}{c}\text { Avg. TCE } \\
\text { (ug/L) }\end{array}$ \\
\hline TNX-8D & 3.4 & TNX-37D & $<1$ \\
\hline TNX-9D & $<1$ & TNX-36D & 1.6 \\
\hline TNX-10D & 13.3 & TNX-26D & $<1$ \\
\hline TCM-2 & 84.7 & TNX-35D & $<1$ \\
\hline TNX-11D & 3.1 & TNX-34D & 1.5 \\
\hline \multirow[t]{12}{*}{ TNX-12D } & $<1$ & TNX-33D & 11.1 \\
\hline & & TNX-32D & 6.5 \\
\hline & & TNX-31D & 13.6 \\
\hline & & TNX-30D & 28.6 \\
\hline & & TIR-1U & 37.1 \\
\hline & & TCM-7 & 45.6 \\
\hline & & TCM-6 & 55.3 \\
\hline & & TCM-8 & 66.5 \\
\hline & & TCM-5 & 49.9 \\
\hline & & TCM-4 & 26.4 \\
\hline & & TNX-29D & 33.8 \\
\hline & & TNX-28D & 3.2 \\
\hline
\end{tabular}

Based on the results from the sampling shown in Figure 2 the extent of groundwater with greater than 5 $\mathrm{ug} / \mathrm{L}$ TCE along the proposed line of GeoSiphon cells ( SRS East 16170) is 745 feet wide and extends from from SRS North 70580 to SRS North 71325.

\section{TGSC-2}

Well TGSC-2 is a GeoSiphon cell that was installed in September 1998 and is a well 20 feet deep and 8 feet in diameter with a granular cast iron filter pack and a 12" diameter stainless steel screen and casing. The cell was constructed by hammering a 102" diameter caisson to 25 feet and removing the soil inside the caisson to a depth of 20 feet. After the soil was removed the borehole was dewatered and a 96 " diameter rebar cage with a geonet with geotextile around the outside and a 12" diameter stainless steel screen in the center was lowered into the dry borehole. The rebar cage was then backfilled with $100,000 \mathrm{lbs}$ of granular cast iron capped with a thick sheet of high-density polyethylene. The caisson was removed using a vibratory hammer and groundwater rapidly entered the newly constructed cell. Bentonite and consolidated low strength material (CLSM) were used to backfill the cell to grade. This new method of cell construction allowed placement of the granular iron in a dry borehole prior to caisson removal that minimized the amount of natural fine grained material entering the cell and coating the iron. 


\section{Field Data}

The results from the analysis of field parameters changed between the initial and final samples from TGSC-2 with the $\mathrm{pH}$, specific conductivity, and redox potential increasing significantly (Table 3 ). All of the field data is included in Appendix B. The final $\mathrm{pH}$, specific conductivity, and redox potential are typical for wells constructed with a granular iron filter pack.

Table 3. Field data for GeoSiphon Cell TGSC-2.

\begin{tabular}{lcccc}
\hline Sample Date & $\begin{array}{c}\text { PH } \\
\text { (pH.Units) }\end{array}$ & $\begin{array}{c}\text { Specific } \\
\text { Conductivity } \\
\text { (mS/cm) }\end{array}$ & $\begin{array}{c}\text { DO } \\
\text { (mg/L) }\end{array}$ & Eh (mV) \\
\hline $12 / 9 / 98$ & 6.62 & 0.256 & 0 & -311 \\
$1 / 19 / 99$ & 7.31 & 0.422 & 0 & -48 \\
$3 / 4 / 99$ & 10.08 & 0.414 & 0 & 3 \\
'TGSC-1 (9/97 to 9/98) & 8.7 to 9.6 & $\mathrm{ND}$ & 1 to 2 & -12 to -140 \\
$\begin{array}{l}\text { Groundwater in TNX } \\
\text { floodplain }\end{array}$ & 4.5 to 6 & 0.05 to 0.12 & 0.6 to 3.2 & 337 to 577 \\
Note: 'TGSC-1 is a GeoSiphon cell that was installed in July 1997, Phifer et. al. 1998 and 1999.
\end{tabular}

Flowrate and water level data collected during well development and initial sampling indicated that the new GeoSiphon cell TGSC-2 has a higher specific capacity than the original GeoSiphon cell TGSC-1, Table 4. The improved specific capacity will produce less drawdown and subsequently higher flowrates during normal operation of the GeoSiphon cell. The estimated flowrates for the current dual cell system based on average water table conditions are included in Table 4 for comparison.

Table 4. Specific capacity of TGSC-1 and TGSC-2.

\begin{tabular}{lcccc}
\hline & $\begin{array}{c}\text { Flowrate } \\
\text { during } \\
\text { sampling } \\
\text { (gpm) }\end{array}$ & $\begin{array}{c}\text { Drawdown } \\
\text { (ft) }\end{array}$ & $\begin{array}{c}\text { Specific } \\
\text { Capacity } \\
\text { (gpm/ft) }\end{array}$ & $\begin{array}{c}\text { Estimated flowrate } \\
\text { for average water } \\
\text { table conditions } \\
\text { (gpm) }\end{array}$ \\
\hline TGSC-1 & ND & ND & $2.24^{\prime}$ & 7.2 \\
TGSC-2 & 8.33 & 1.27 & 6.5 & 16.4 \\
\hline
\end{tabular}

Note: 'Phifer et. al. (1999).

\section{Chlorinated Volatile Organic Compounds}

Samples were collected from GeoSiphon cell TGSC-2 to determine if the cell was degrading all of the CVOCs that entered the granular iron. The influent TCE and carbon tetrachloride concentrations were determined to be $50 \mathrm{ug} / \mathrm{L}$ and $2 \mathrm{ug} / \mathrm{L}$ respectively based on results from wells TCM6 and TCM7 that are located next to TGSC-2, see Figure 1. The TCE concentration in TGSC-2 decreased from an initial concentration of $22 \mathrm{ug} / \mathrm{L}$ in December 1998 to $2.5 \mathrm{ug} / \mathrm{L}$ by March 1998. These results suggest that the initial samples were of water that rapidly filled the cell during removal of the cassion in construction and did not represent water that had been treated by the iron. Subsequent sampling events removed more and more of the water left over from construction and as a result the water being sampled was more representative of water that had been treated by the granular iron filter pack. 


\section{Piezometers}

Water levels were measured in the new piezometers TNX38D, 39, and 40D for three consecutive months, Table 5. The new piezometers are located north of TNX Area around a surface depression that receives excess production water from TNX and occasional discharges from a half-tank used to test pumps for the tank farms at SRS. Water levels in the new piezometers are significantly above the water table levels immediately south in the TNX Area. The high water levels may be due to a perched water table or local recharge of the water table from the surface depression.

Table 5. Water elevation ( $\mathrm{ft}, \mathrm{msl}$ ) in new piezometers.

\begin{tabular}{cccc}
\hline Date & TNX 38D & TNX 39D & TNX 40D \\
\hline $1 / 13 / 99$ & 115.26 & 118.32 & 114.44 \\
$2 / 10 / 99$ & 114.65 & 116.24 & 107.6 \\
$3 / 16 / 99$ & 114.49 & 115.62 & 107 \\
\hline
\end{tabular}

\section{Conclusions}

All of the wells installed as part of this study produced high quality samples and water level information. Results from monitoring wells sampled in the TNX swamp show that groundwater contaminated with TCE above the Primary Drinking Water Standard of $5 \mathrm{ug} / \mathrm{L}$ is bounded to the north by SRS North 71325 and to the south by SRS North 70580 on a profile extending along $\sim$ SRS East 16170. The existing GeoSiphon cells are located in the center of the plume at the highest concentrations along the profile and are capable of remediating a significant portion of the contaminated groundwater migrating from TNX Area into the swamp. The previously installed wells provided a good indication of the location of the most contaminated groundwater in the swamp and the newer wells delineated the north-south extent of CVOC contamination.

GeoSiphon cell TGSC-2 is capable of treating CVOC contaminated groundwater migrating from the TNX Area to levels acceptable for discharge at the X-019 NPDES outfall. The cell produces treated water of a chemistry similar to the existing GeoSiphon cell TGSC-1. Preliminary data suggest that the new construction methods used to install TGSC-2 produced a well that will operate at higher flowrates than TGSC-1 under normal siphon conditions producing a larger capture zone for the same operating head differential.

\section{References}

40CFR, Code of Federal Regulations: Title 40 Protection of Environment Subpart G -\$141.61 National Revised Primary Drinking Water Regulations: Maximum Contaminant Levels. (1989).

EPA, 1995. Test Methods for Evaluating Solid Waste, Method 5021 Volatile Organic Compounds in Soils and Other Solid Matrices Using Equilibrium Headspace Analysis. EPA. Publication SW 846.

ETI, 1996. ETI Reference : 31054.10 , EnviroMetal Technologies, Inc., Feasibility Study Report, CVOC Iron Degradation Study Using Groundwater from the TNX Area, Savannah River Technology Center, Aiken, South Carolina, July 1996.

Looney, B. B., C. A. Eddy, and W. R. Sims. "Evaluation of Headspace Method for Volatile Constituents in Soils and Sediments". Measuring and Interpreting VOCs in Soils: State of the Art and Research Needs, US Environmental Protection Agency, Environmental Monitoring Systems Laboratory, Las Vegas NV 89193 (1993). 
Nichols, R. L. Well Installation Report for Monitoring Wells TCM4, TCM5, and TCM8 and Pilot Hole TGSC-2A (U). WSRC-TR-98-00247, Rev.0. Savannah River Site, Aiken SC 29808 (1998).

Phifer, M.A., F.C. Sappington, M.E. Denham. TNX GeoSiphon Cell (TGSC-1) Phase 1 Deployment / Demonstration Final Report (U). WSRC-TR-98-00032, Rev.0. Savannah River Site, Aiken SC 29808 (1998).

Phifer, M.A., F.C. Sappington, R. L. Nichols, K. L. Dixon. TNX GeoSiphon Cell (TGSC-1) Phase II Deployment / Demonstration Final Report (U). WSRC-TR-98-00432, Rev.0. Savannah River Site, Aiken SC 29808 (1999). 


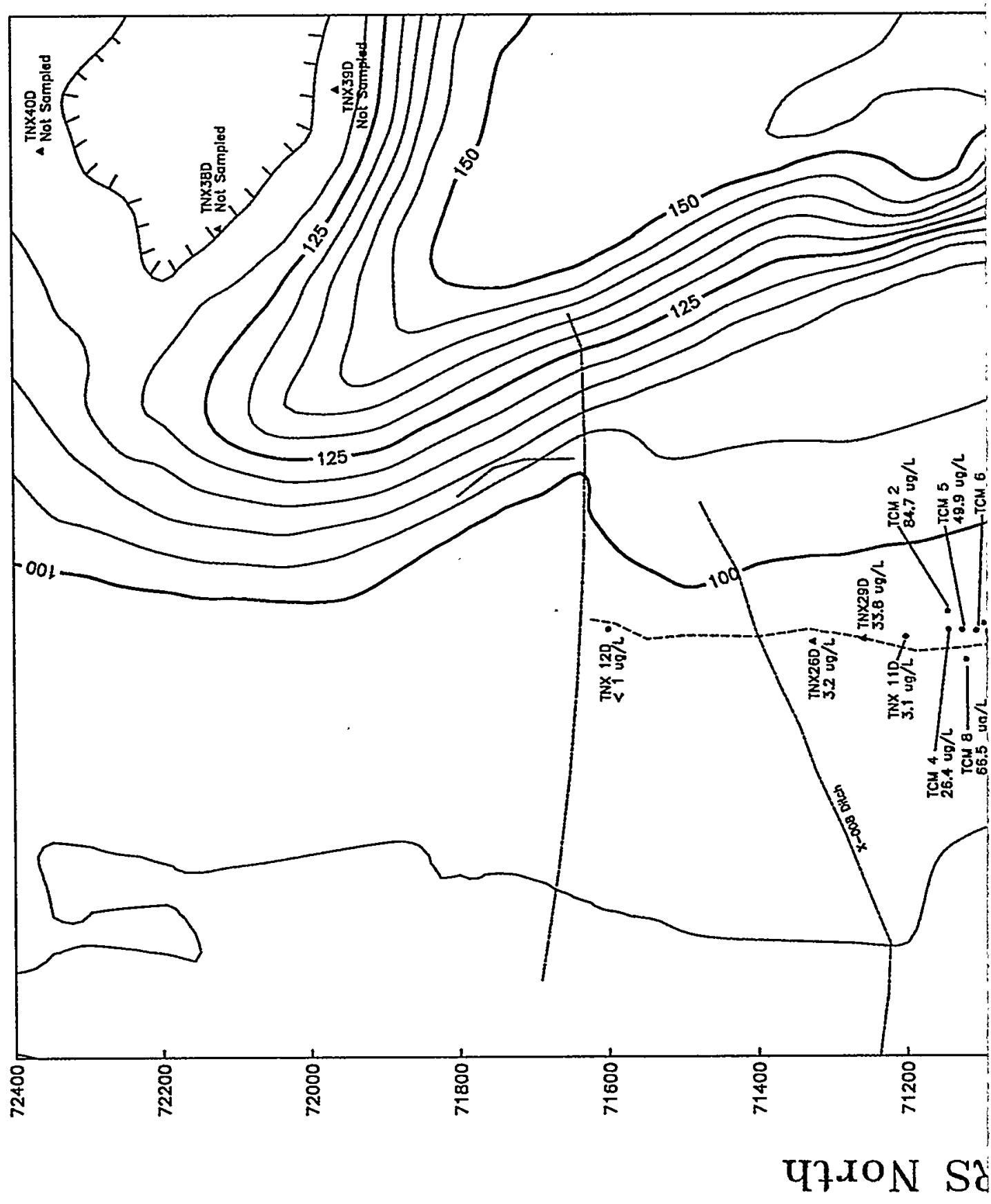




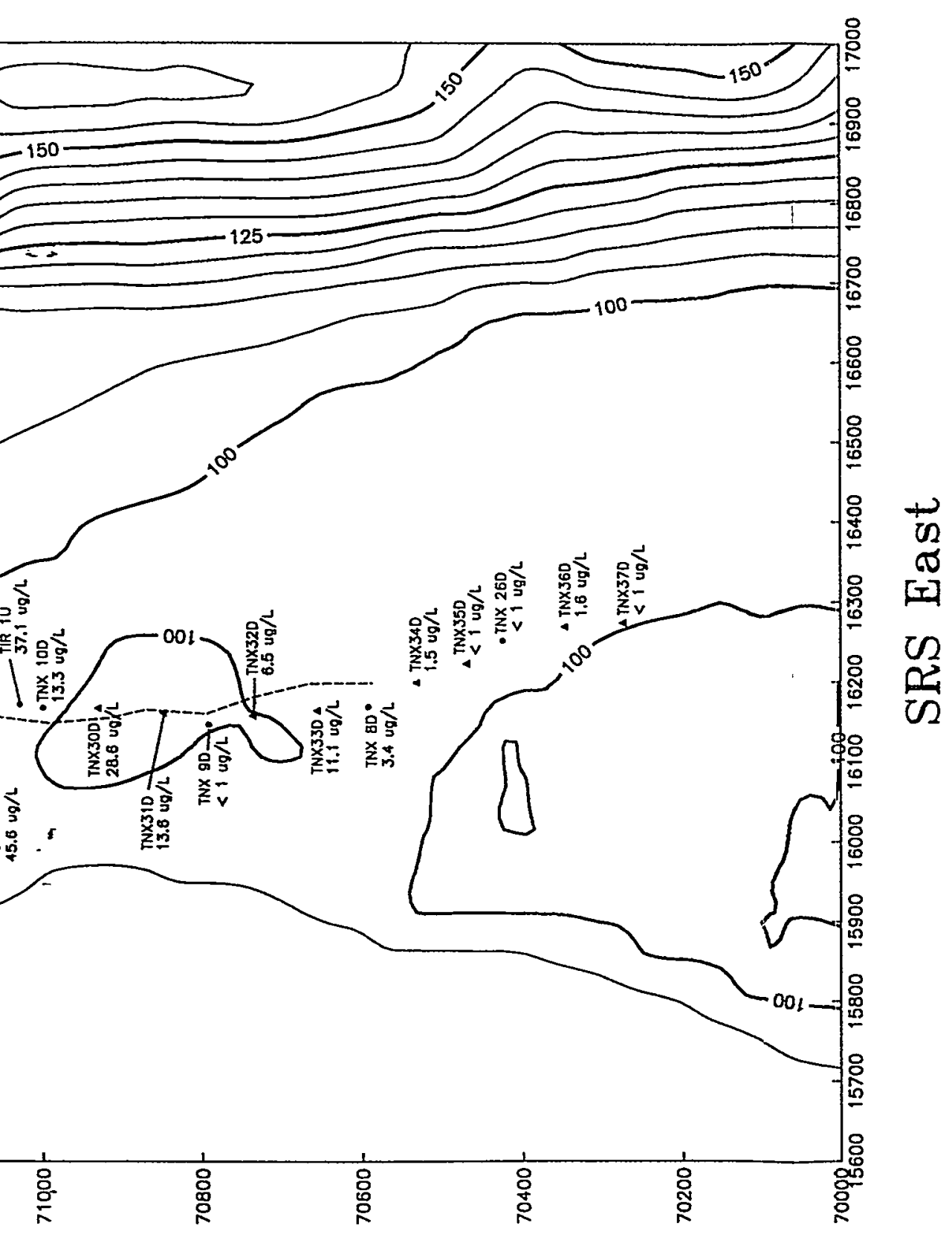


Figure 2. Trichloroethylene profile at TNX Area along SRS East 16170

Trichloroethylene Profile @ SRS East 16170

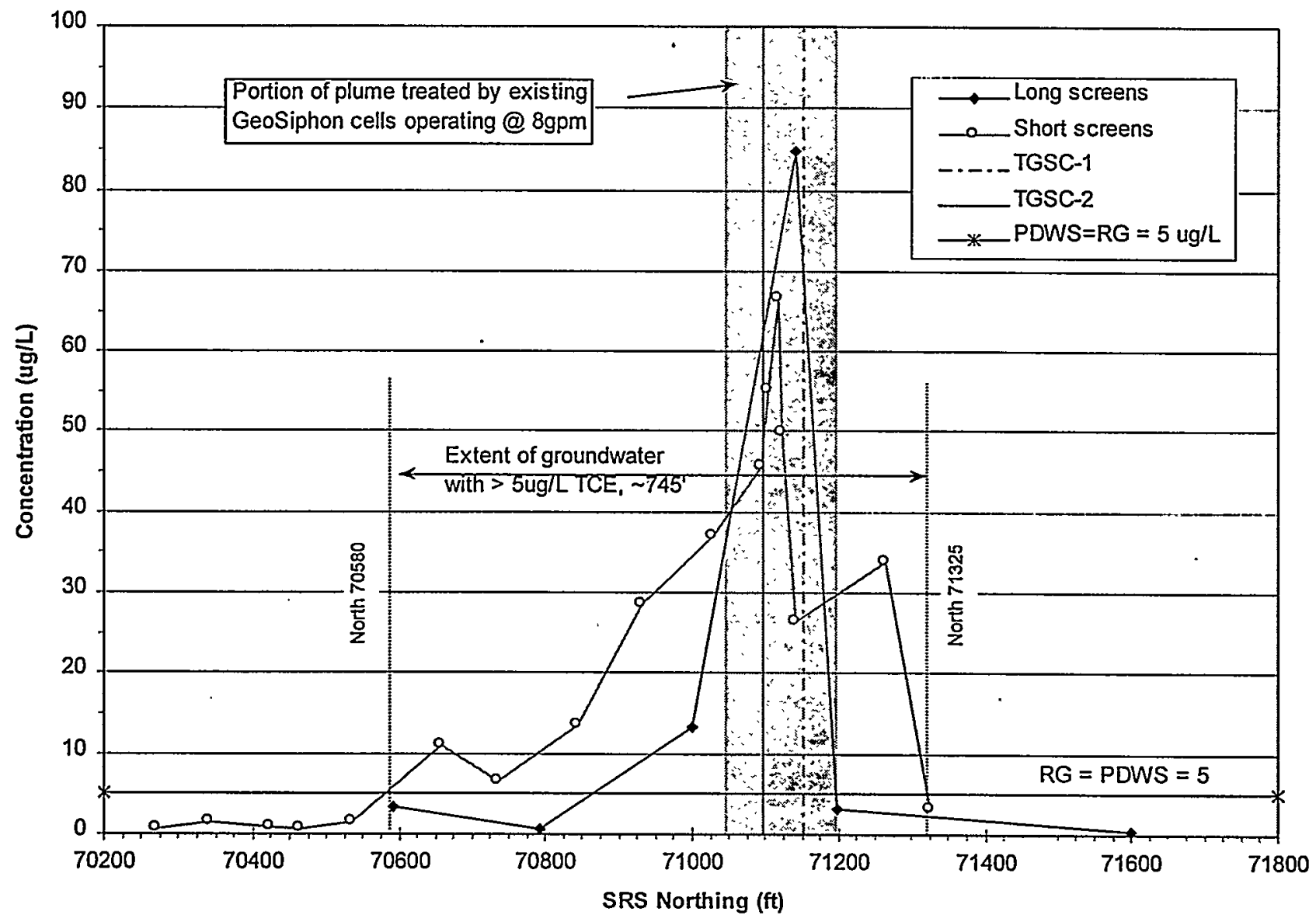


Figure 3. Vertical placement of monitoring well screens in the TNX swamp.

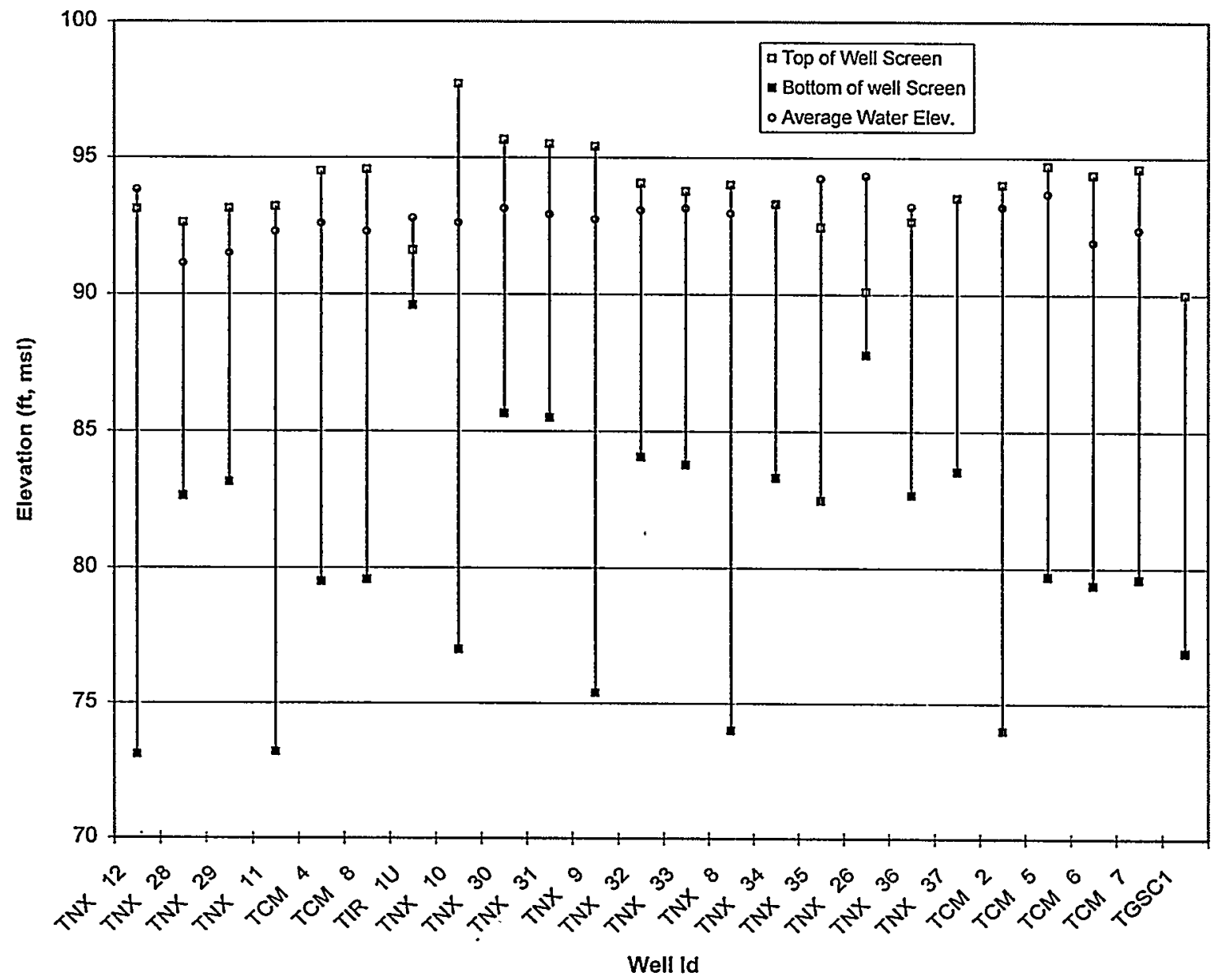


Appendix A

Well Construction Diagrams 


\section{Monitoring Well Construction Diagram}

\begin{tabular}{|c|c|c|}
\hline $\begin{array}{l}\text { Drilling Subcontractor } \\
\text { Graves }\end{array}$ & & $\begin{array}{l}\text { Driller } \\
\text { John Johns }\end{array}$ \\
\hline $\begin{array}{l}\text { Date of Well Installation } \\
9.17 .98\end{array}$ & $\begin{array}{l}\text { Tech O.S./CO. Name } \\
\text { Ralph L. Nichols }\end{array}$ & \\
\hline $\begin{array}{l}\text { Well Number } \\
\text { TGSC-2 } \\
\end{array}$ & $\begin{array}{l}\text { SRS Coordinates } \\
\text { North 71096.41, East } 16172.48\end{array}$ & $\begin{array}{l}\text { Sanitary Seal Elevation } \\
97.56 \text { ft. m.s.l. }\end{array}$ \\
\hline
\end{tabular}

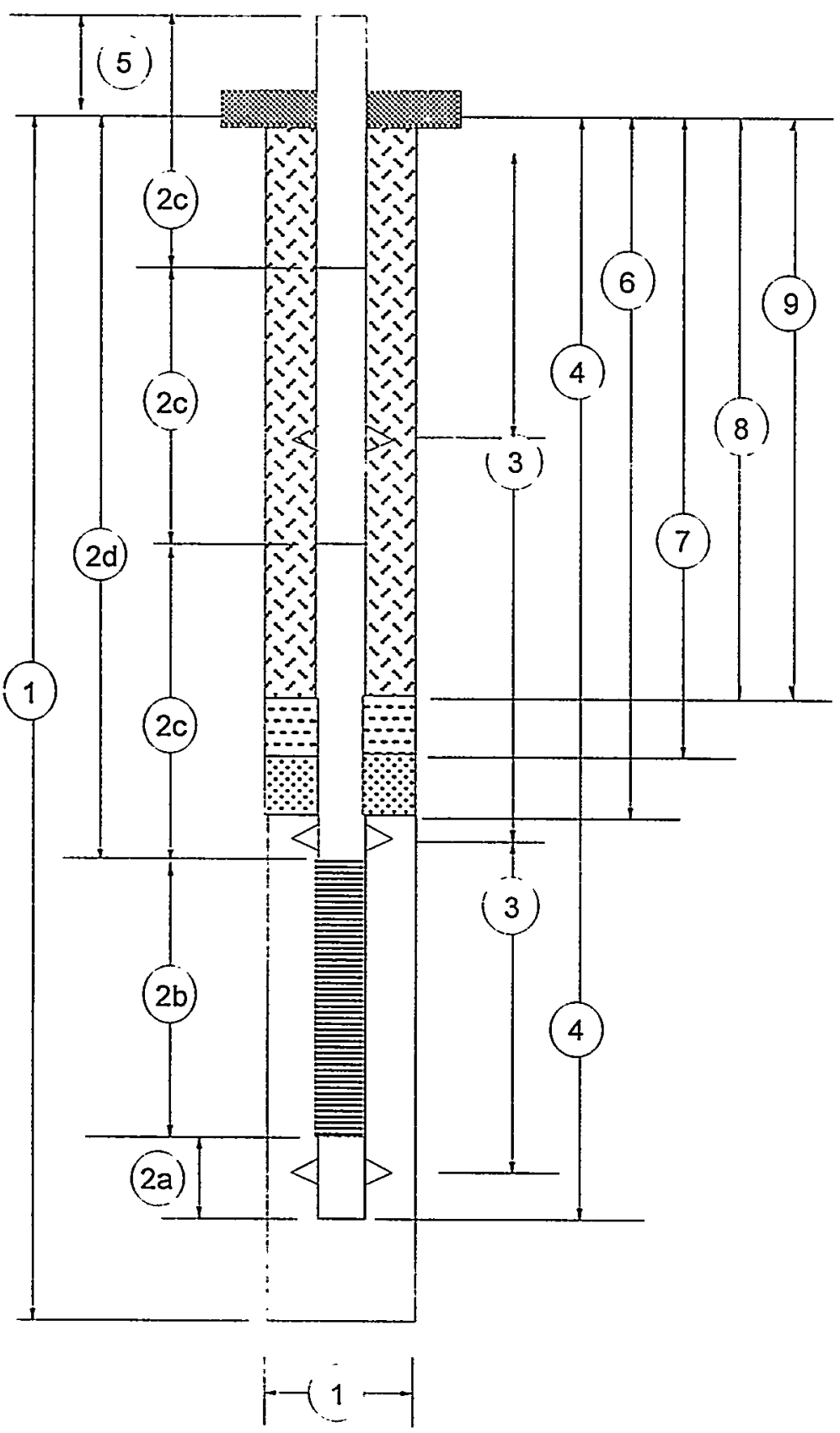

Note-All measurements are from ground surface at start of boring (measurements to nearest 0.1 foot).

1. Total Drilled Depth/Hole Diameter 20 feet / 102 inches

2. Casing/Screen Tally (Measured to Nearest 0.01 foot)

a) Sump and Plug Length 2.75 feet

b) Screen Length 15 feet

c) Casing Joint Lengths (Measured in Uphole Sequence from Top of Screen) 5 feet

d) Depth to Top of Screen 5 feet

3. Depths to Centralizers n.a.

4. Total Depth of Installed Well 20 feet

5. Casing Stick Up (Standard 2.5' A.G.S.) 2.75 feet

6. Depth to Top of Filter Pack 6 feet

7. Depth to Top of Fine Sand Seal n.a.

8. Depth to Top of Bentonite Seal 5 feet

9. Thickness of Grout 5 feet 
Monitoring Well Construction Diagram

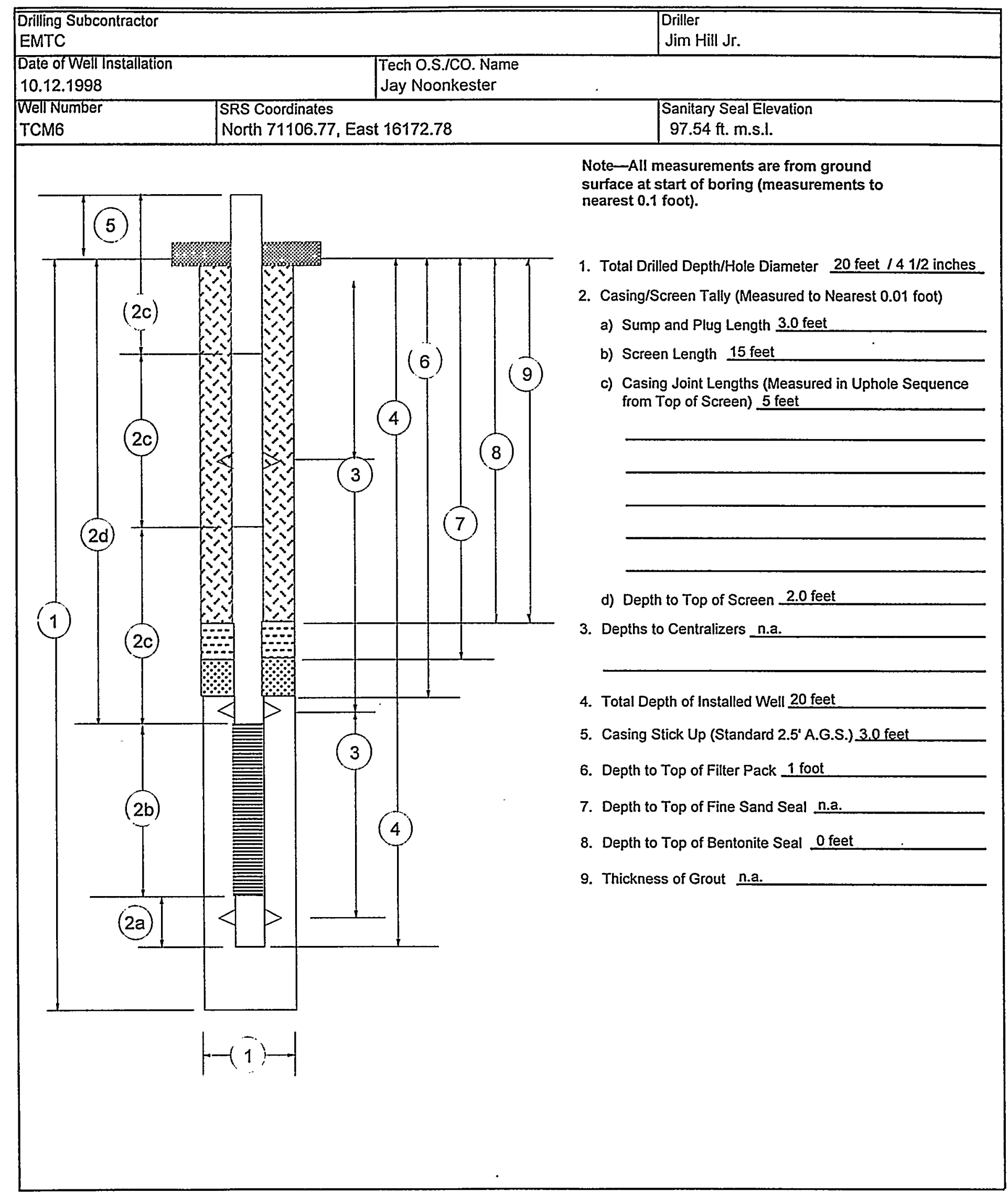




\section{Monitoring Well Construction Diagram}

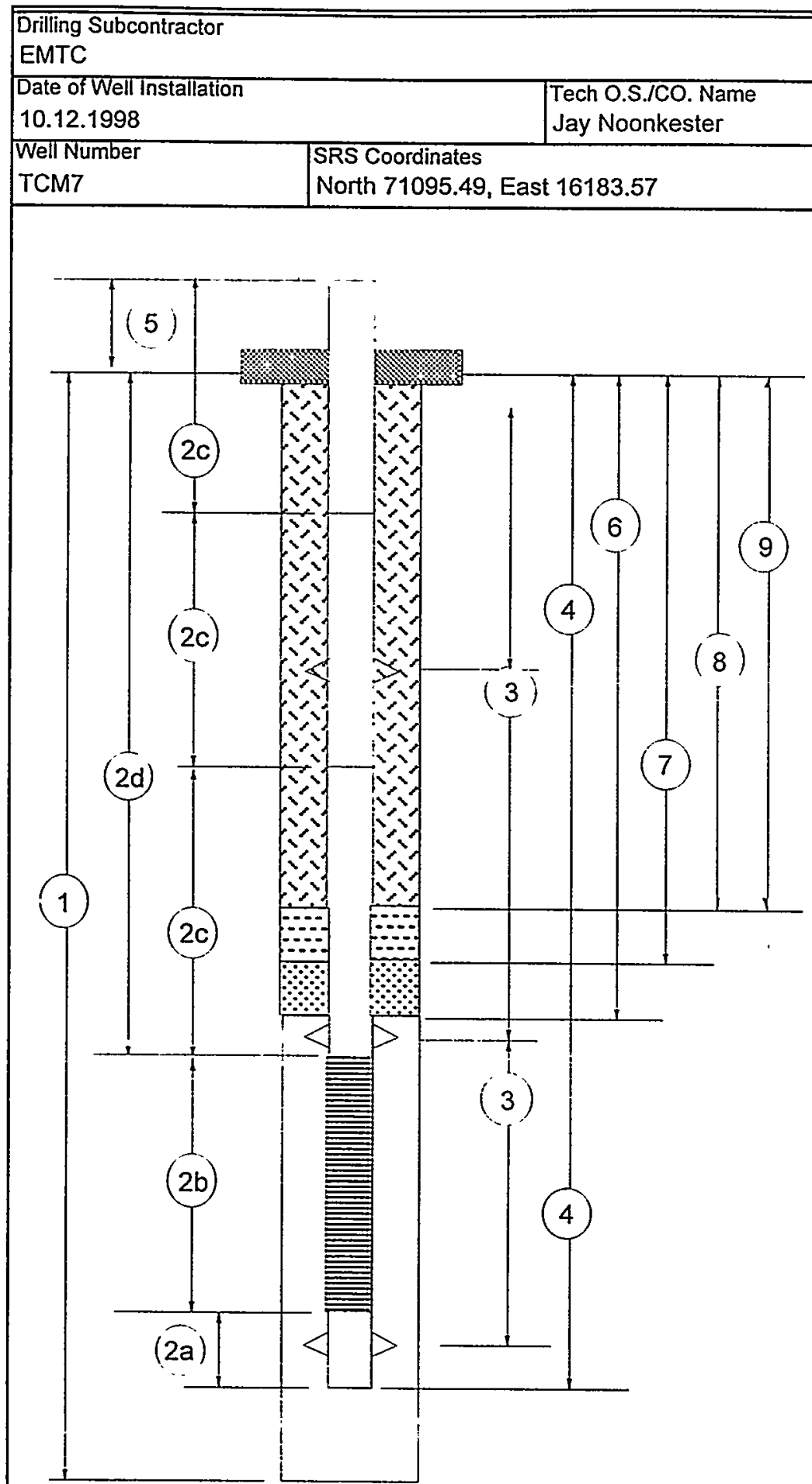

Driller

Jim Hill Jr.
Note-All measurements are from ground surface at start of boring (measurements to nearest 0.1 foot).

1. Total Drilled Depth/Hole Diameter 20 feet $/ 41 / 2$ inches

2. Casing/Screen Tally (Measured to Nearest 0.01 foot)

a) Sump and Plug Length 3.0 feet

b) Screen Length 15 feet

c) Casing Joint Lengths (Measured in Uphole Sequence from Top of Screen) 5 feet

d) Depth to Top of Screen 1.75 feet

3. Depths to Centralizers n.a.

4. Total Depth of Installed Well 20 feet

5. Casing Stick Up (Standard 2.5' A.G.S.) 3.25 feet

6. Depth to Top of Filter Pack 1 foot

7. Depth to Top of Fine Sand Seal n.a.

8. Depth to Top of Bentonite Seal 0 feet

9. Thickness of Grout n.a. 


\section{Monitoring Well Construction Diagram}

\begin{tabular}{|c|c|c|}
\hline $\begin{array}{l}\text { Drilling Subcontractor } \\
\text { AEI }\end{array}$ & & $\begin{array}{l}\text { Driller } \\
\text { Clarence Coleman }\end{array}$ \\
\hline $\begin{array}{l}\text { Date of Well Installation } \\
11.19 .1998\end{array}$ & $\begin{array}{l}\text { Tech O.S./CO. Name } \\
\text { Jay Noonkester }\end{array}$ & \\
\hline $\begin{array}{l}\text { Well Number } \\
\text { TNX28D }\end{array}$ & $\begin{array}{l}\text { SRS Coordinates } \\
\text { North } 71324.9 \text {, East } 16159.3\end{array}$ & $\begin{array}{l}\text { Sanitary Seal Elevation } \\
97.44\end{array}$ \\
\hline
\end{tabular}

Note-All measurements are from ground surface at start of boring (measurements to

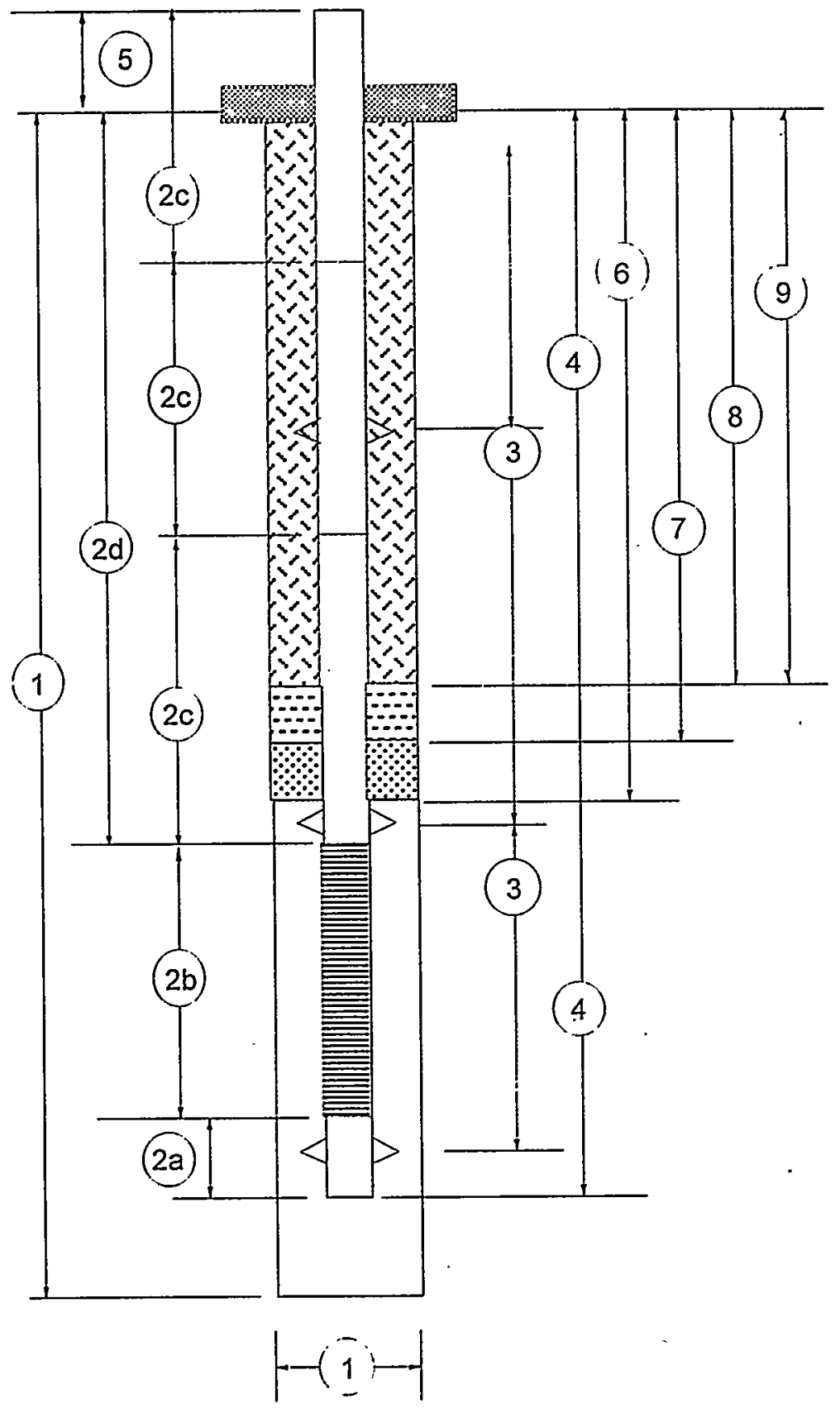
nearest 0.1 foot).

1. Total Drilled Depth/Hole Diameter 15 feet $/ 83 / 8$ inches

2. Casing/Screen Tally (Measured to Nearest 0.01 foot)

a) Sump and Plug Length 0.3 feet

b) Screen Length 10 feet

c) Casing Joint Lengths (Measured in Uphole Sequence from Top of Screen) one $5.0 \mathrm{ft}$. - 2n PVC feet

one $2.2 \mathrm{ft}-2^{n}$ PVC

d) Depth to Top of Screen 4.8 feet

3. Depths to Centralizers n.a.

4. Total Depth of Installed Well 15.1

5. Casing Stick Up (Standard 2.5' A.G.S.) 2.4 feet

6. Depth to Top of Filter Pack 3.0 foot

7. Depth to Top of Fine Sand Seal n.a.

8. Depth to Top of Bentonite Seal 0 feet

9. Thickness of Grout n.a. 


\section{Monitoring Well Construction Diagram}

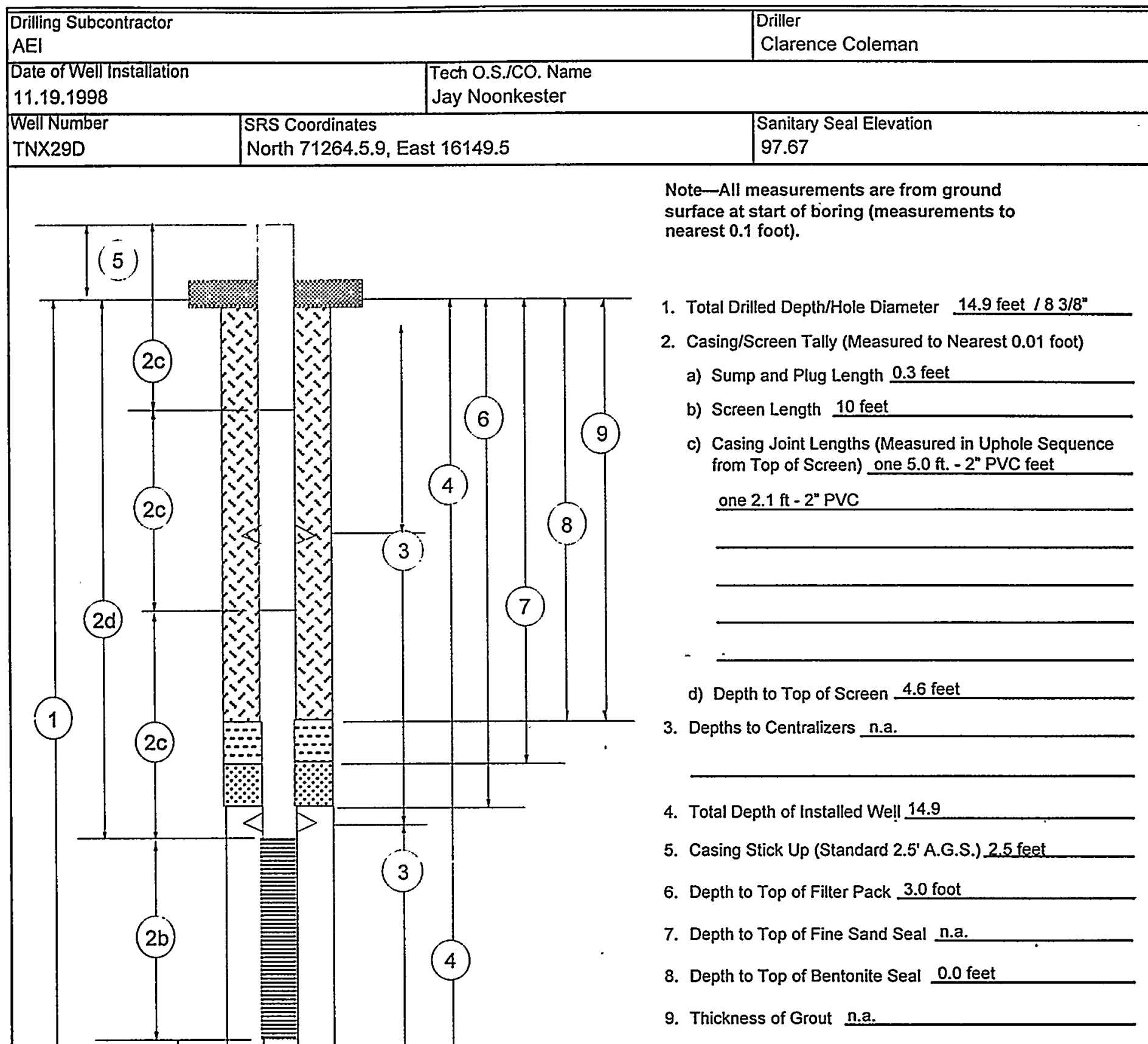




\section{Monitoring Well Construction Diagram}

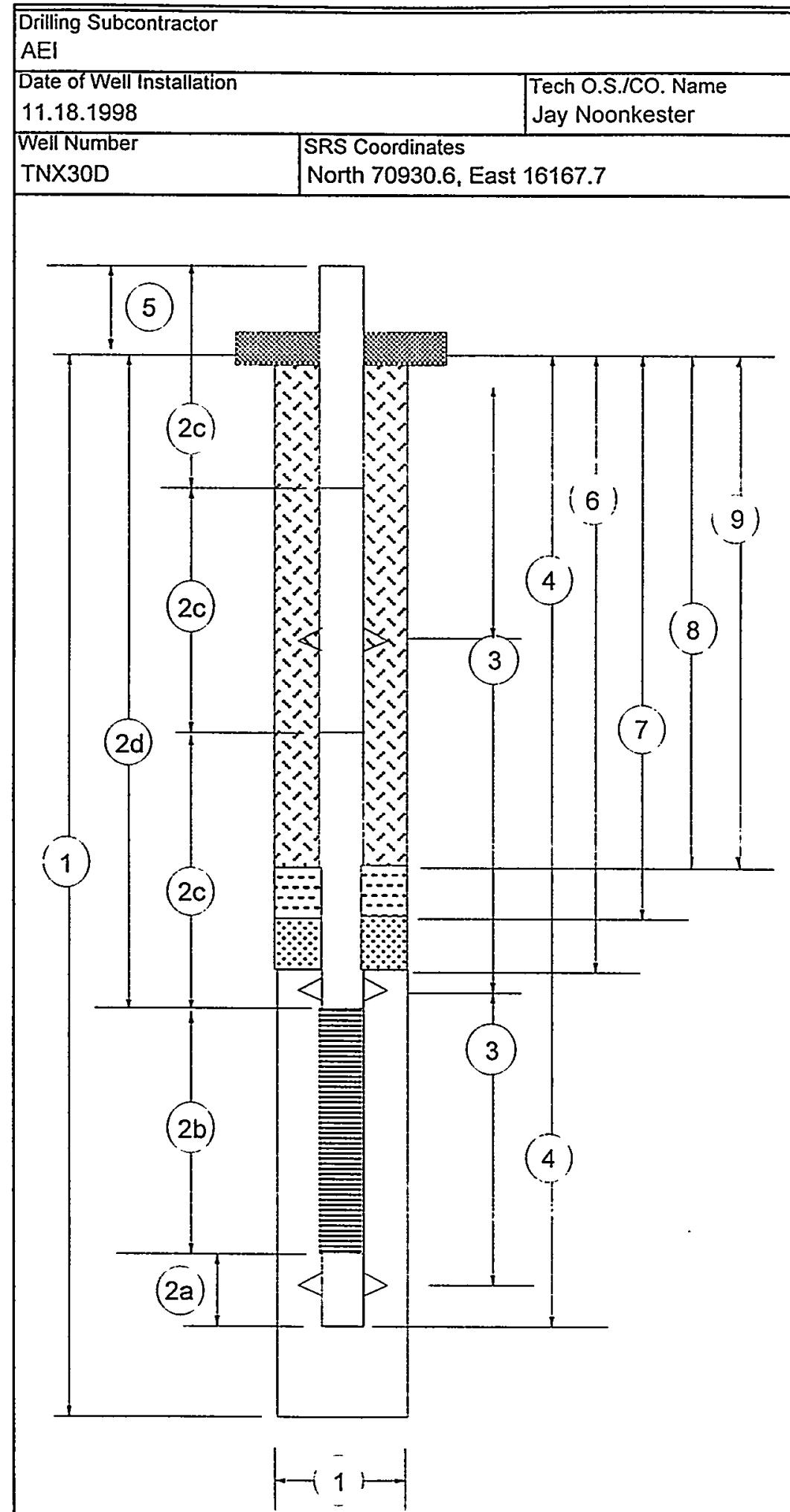

Note-All measurements are from ground surface at start of boring (measurements to nearest 0.1 foot).

1. Total Drilled Depth/Hole Diameter 15.0 feet $/ 83 / 8^{n}$

2. Casing/Screen Tally (Measured to Nearest 0.01 foot)

a) Sump and Plug Length 0.3 feet

b) Screen Length 10 feet

C) Casing Joint Lengths (Measured in Uphole Sequence from Top of Screen) one $5.0 \mathrm{ft}$. - 2" PVC feet

one $2.4 \mathrm{ft}-2^{n}$ PVC

d) Depth to Top of Screen 4.7 feet

3. Depths to Centralizers n.a.

4. Total Depth of Installed Well 14.9

5. Casing Stick Up (Standard 2.5' A.G.S.) 2..7 feet

6. Depth to Top of Filter Pack 3.0 foot

7. Depth to Top of Fine Sand Seal n.a.

8. Depth to Top of Bentonite Seal 0.0 feet

9. Thickness of Grout n.a. 


\section{Monitoring Well Construction Diagram}

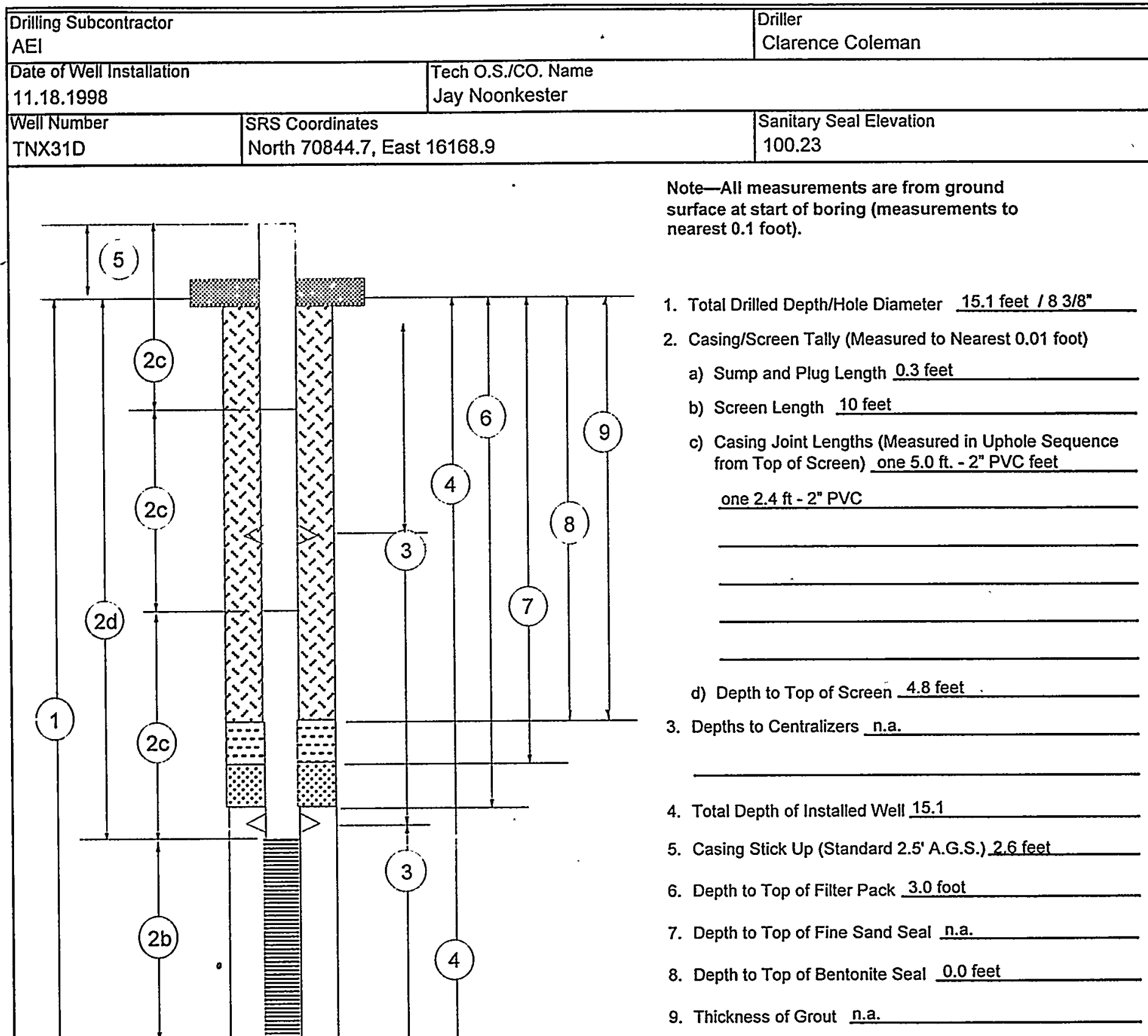




\section{Monitoring Well Construction Diagram}

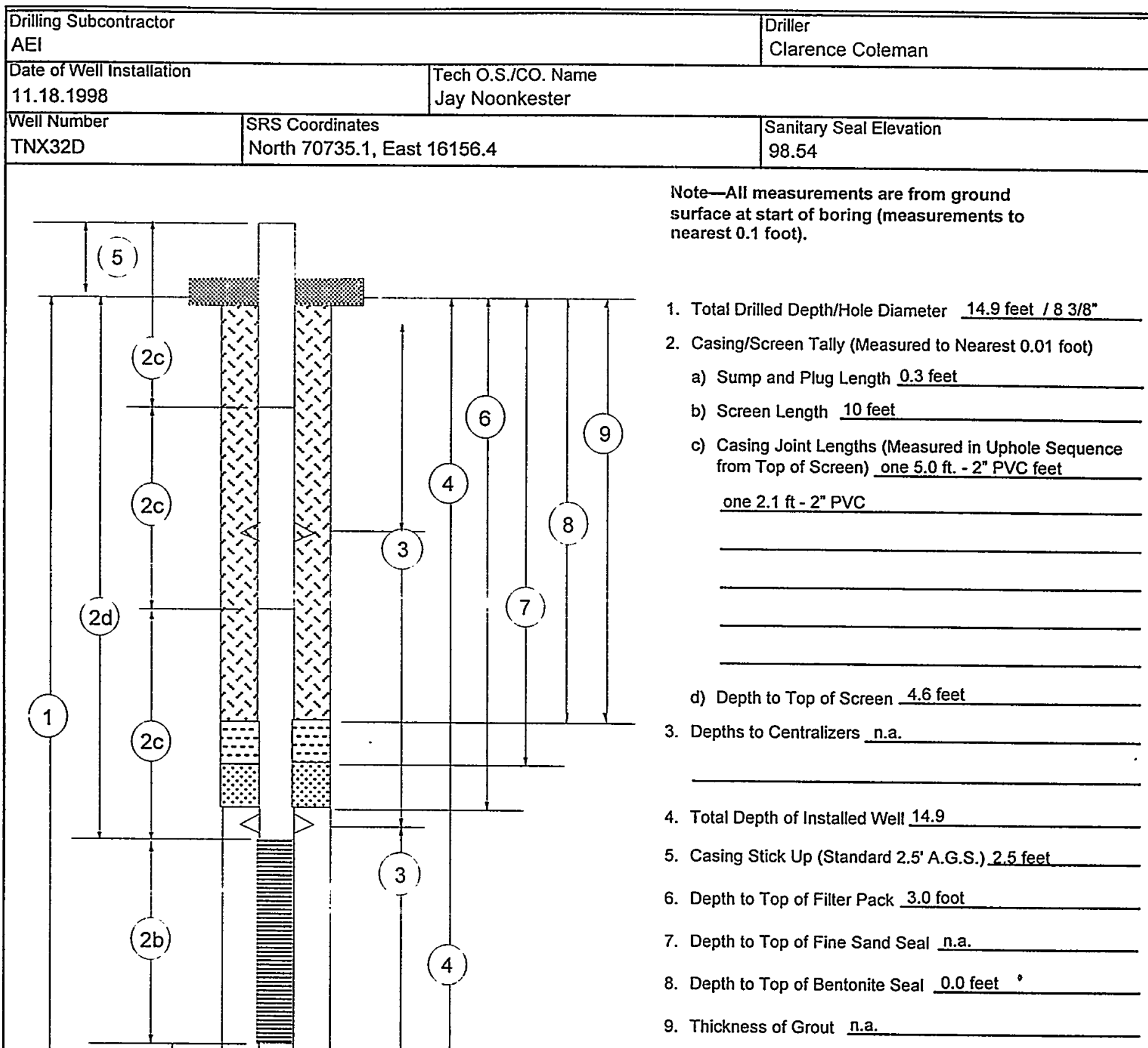




\section{Monitoring Well Construction Diagram}

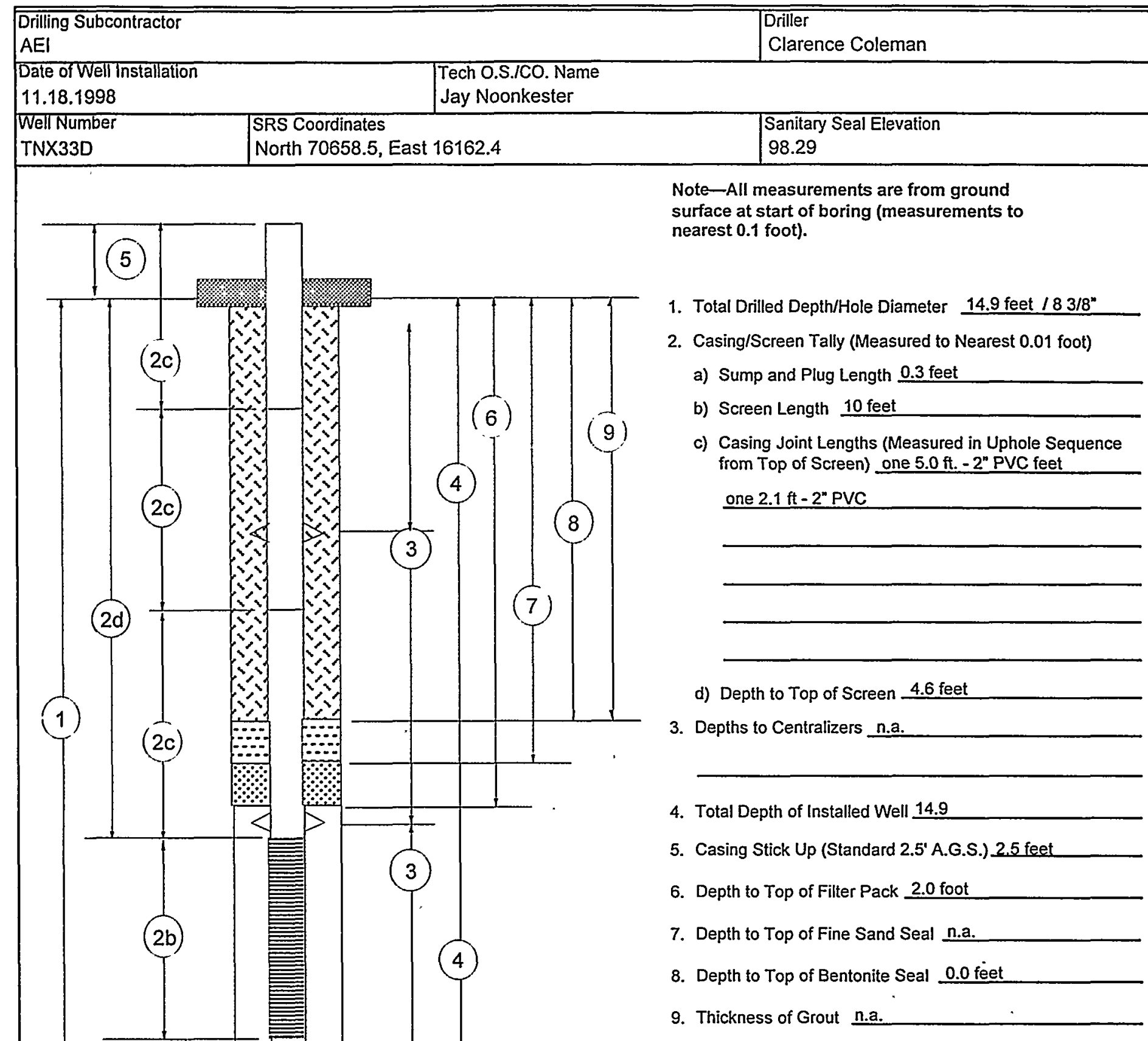<smiles>CC(C)(C)c1ccc(C(C)(C)C)cc1</smiles> 


\section{Monitoring Well Construction Diagram}

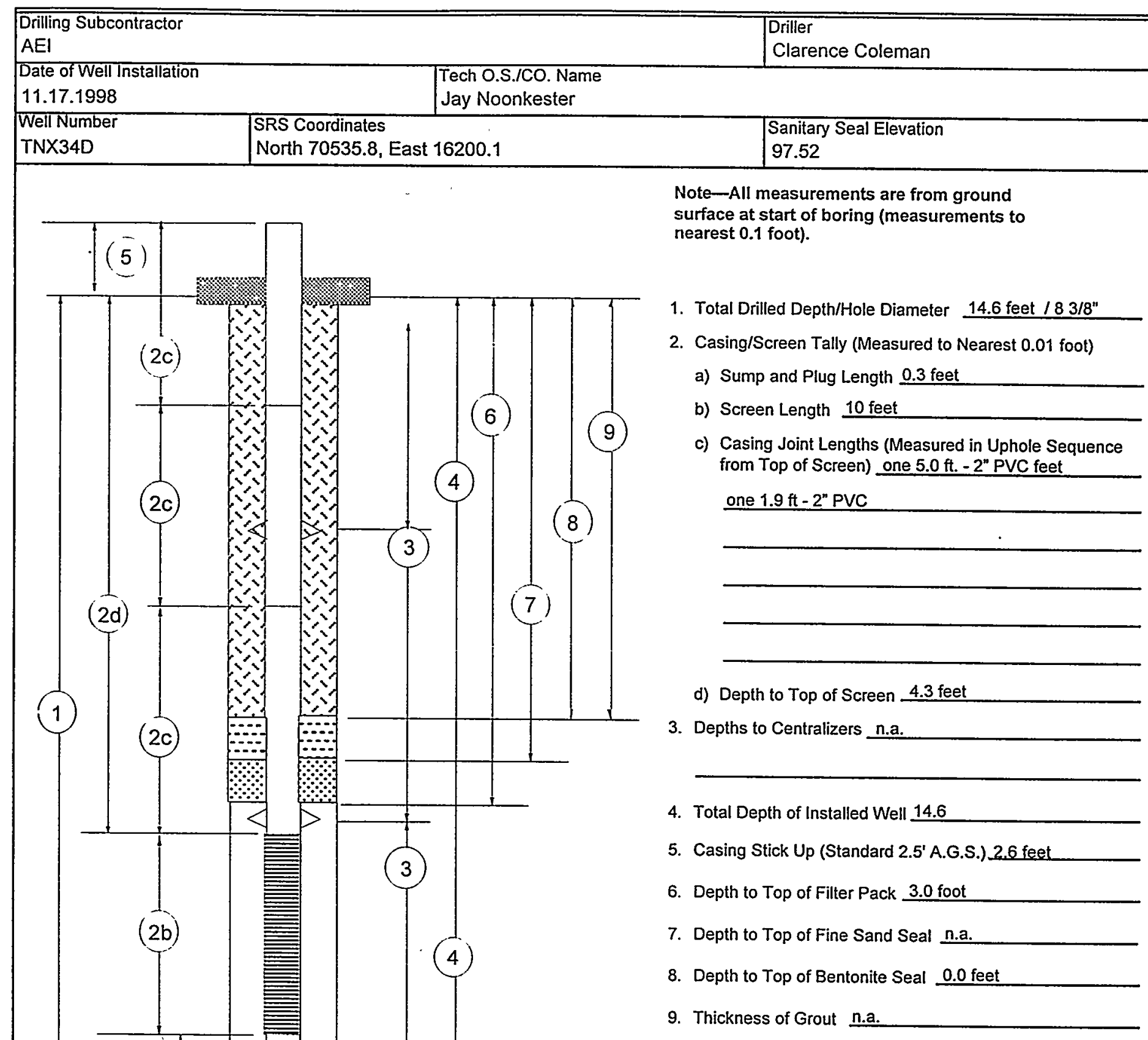




\section{Monitoring Well Construction Diagram}

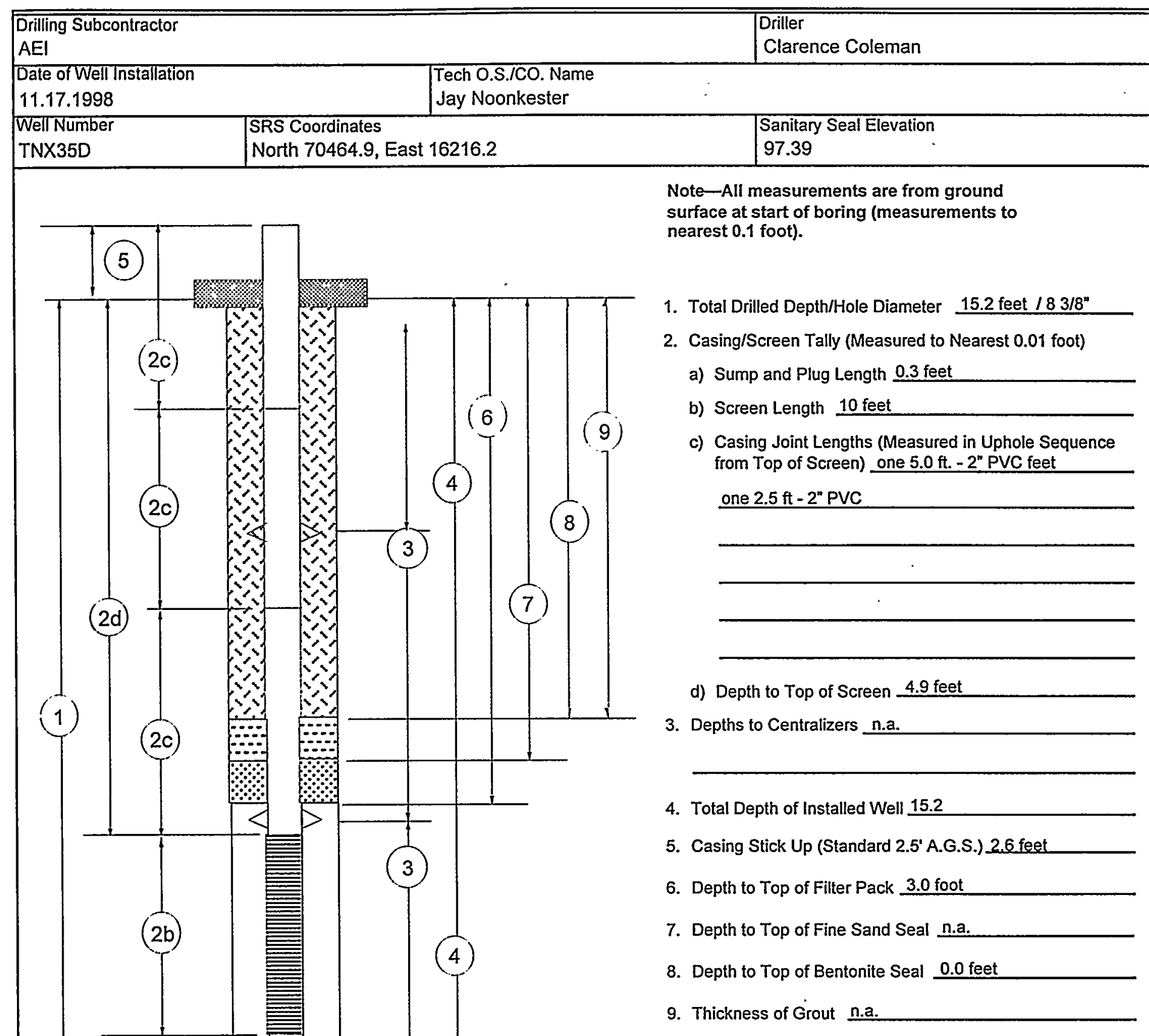




\section{Monitoring Well Construction Diagram}

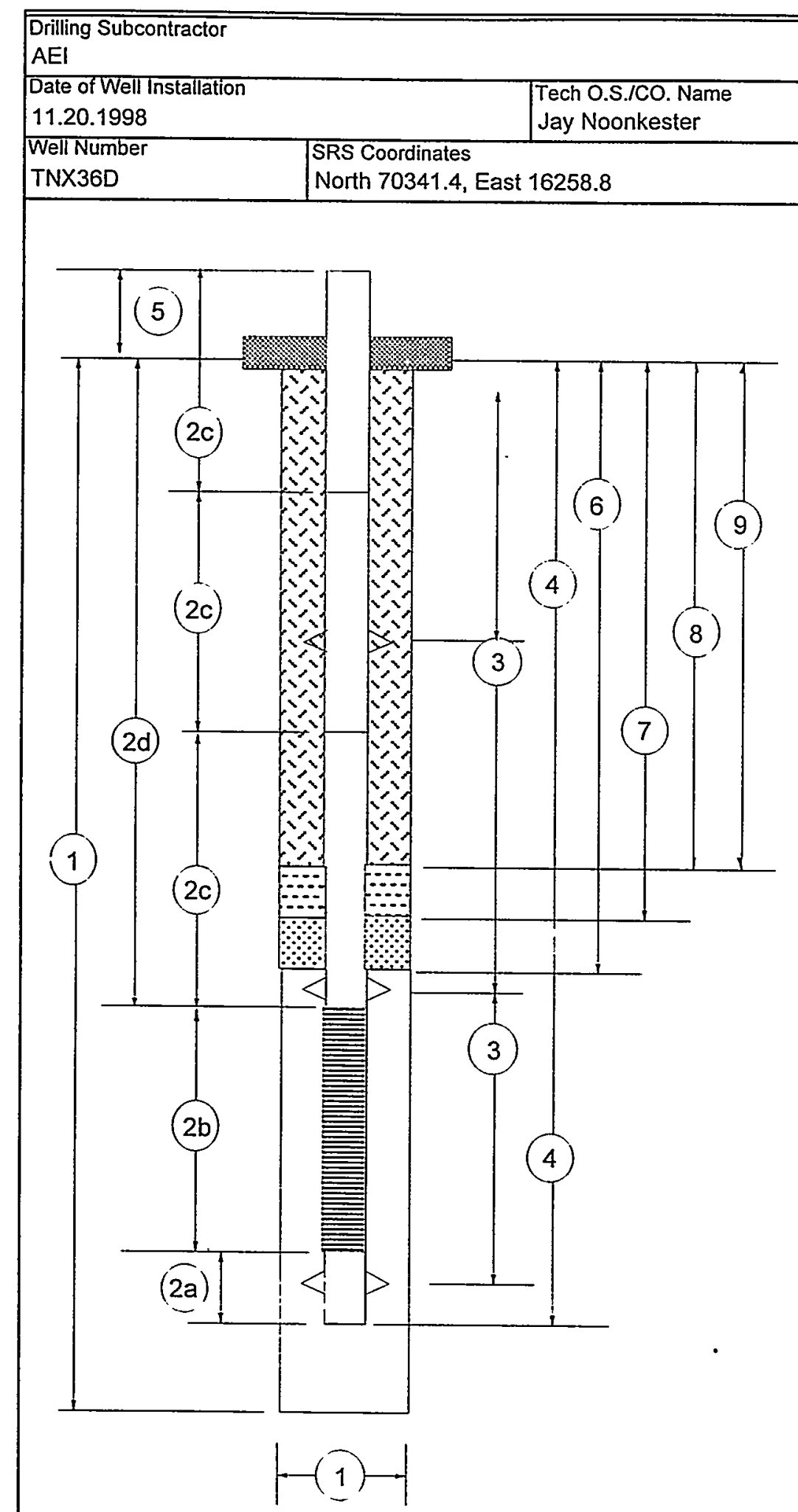

\section{Driller \\ Clarence Coleman \\ Sanitary Seal Elevation \\ 97.35}

Note-All measurements are from ground surface at start of boring (measurements to nearest 0.1 foot).

1. Total Drilled Depth/Hole Diameter 15.0 feet $/ 83 / 8^{n}$

2. Casing/Screen Tally (Measured to Nearest 0.01 foot)

a) Sump and Plug Length 0.3 feet

b) Screen Length 10 feet

c) Casing Joint Lengths (Measured in Uphole Sequence from Top of Screen) one $5.0 \mathrm{ft} .2^{n}$ PVC feet

one $2.2 \mathrm{ft}-2^{\text {" PVC }}$

d) Depth to Top of Screen 4.7 feet

3. Depths to Centralizers n.a.

4. Total Depth of Installed Well 15.0

5. Casing Stick Up (Standard 2.5' A.G.S.) 2.5 feet

6. Depth to Top of Filter Pack 3.0 foot

7. Depth to Top of Fine Sand Seal n.a.

8. Depth to Top of Bentonite Seal 0.0 feet

9. Thickness of Grout n.a. 


\section{Monitoring Well Construction Diagram}

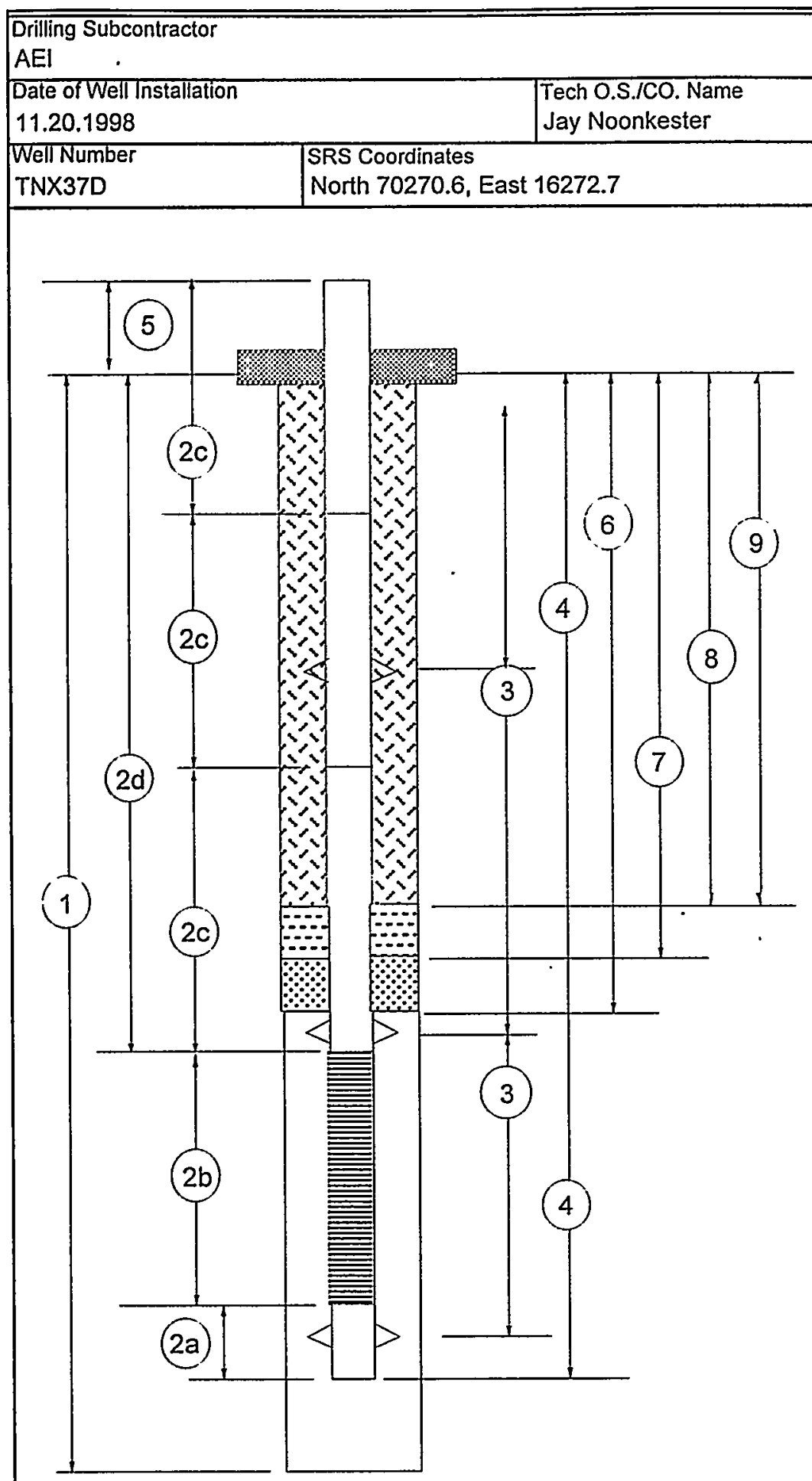

\begin{tabular}{l}
$\mid \begin{array}{l}\text { Driller } \\
\text { Clarence Coleman }\end{array}$ \\
\hline $\begin{array}{l}\text { Sanitary Seal Elevation } \\
98.24\end{array}$ \\
\hline
\end{tabular}

Note-All measurements are from ground surface at start of boring (measurements to nearest 0.1 foot).

1. Total Drilled Depth/Hole Diameter 15.0 feet $/ 83 / 8^{*}$

2. Casing/Screen Tally (Measured to Nearest 0.01 foot)

a) Sump and Plug Length 0.3 feet

b) Screen Length 10 feet

c) Casing Joint Lengths (Measured in Uphole Sequence from Top of Screen) one $5.0 \mathrm{ft} .2^{n}$ PVC feet

one $2.2 \mathrm{ft}-2^{\mathrm{n}} \mathrm{PVC}$

d) Depth to Top of Screen 4.7 feet

3. Depths to Centralizers n.a.

4. Total Depth of Installed Well 15.0

5. Casing Stick Up (Standard 2.5' A.G.S.) 2.5 feet

6. Depth to Top of Filter Pack 3.0 foot

7. Depth to Top of Fine Sand Seal n.a.

8. Depth to Top of Bentonite Seal 0.0 feet

9. Thickness of Grout n.a.

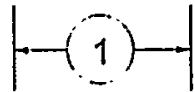




\section{Monitoring Well Construction Diagram}

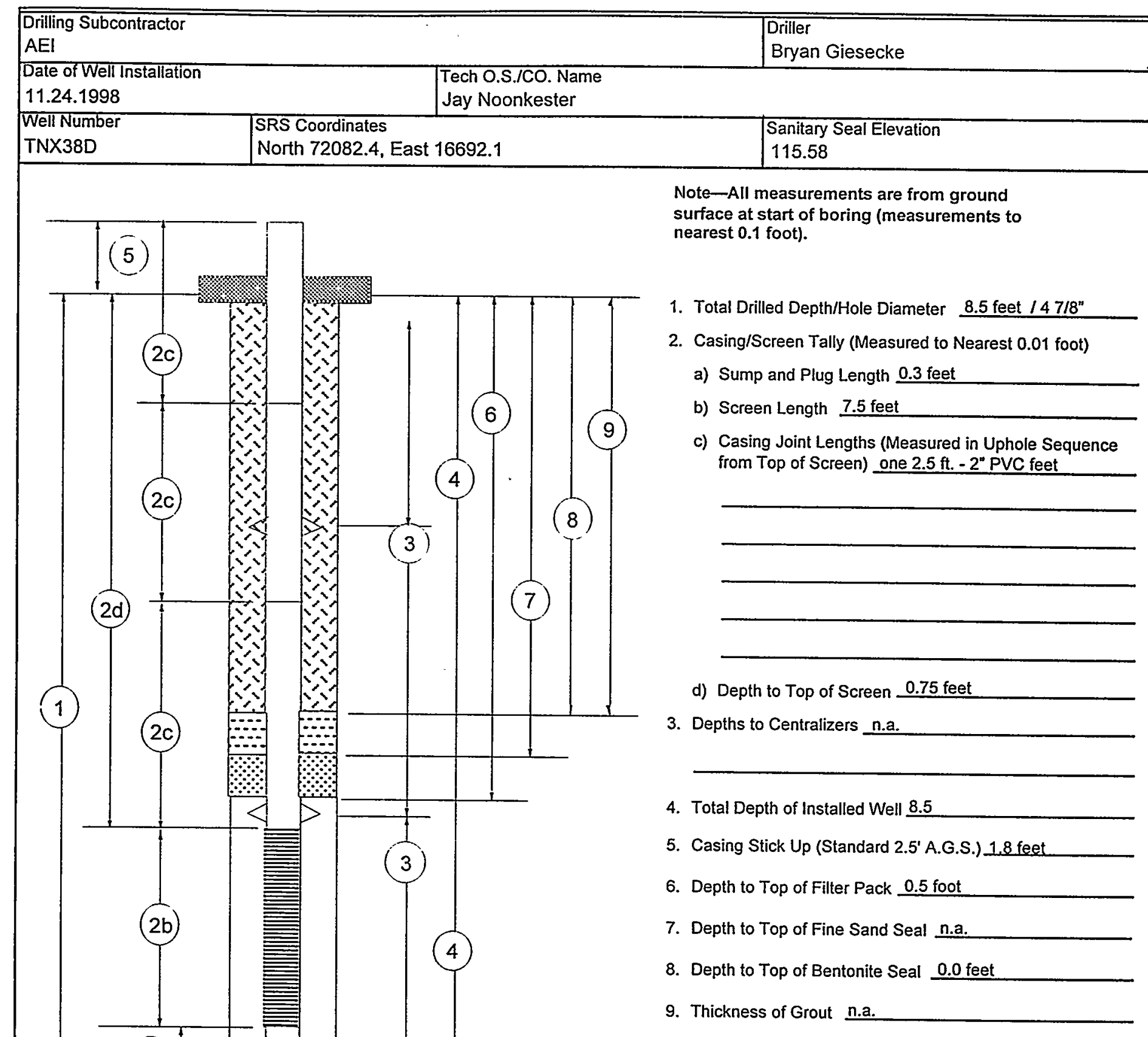




\section{Monitoring Well Construction Diagram}

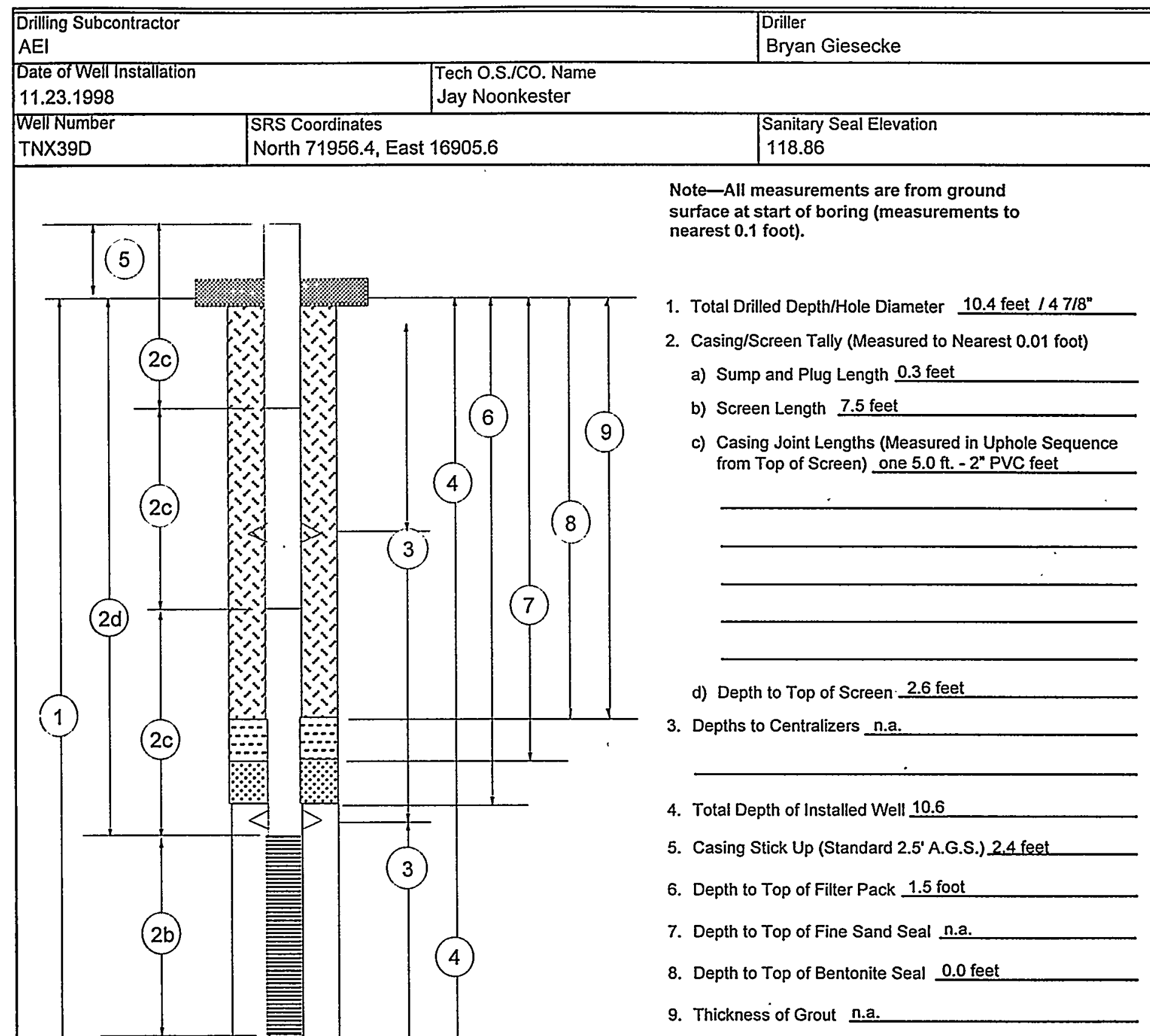




\section{Monitoring Well Construction Diagram}

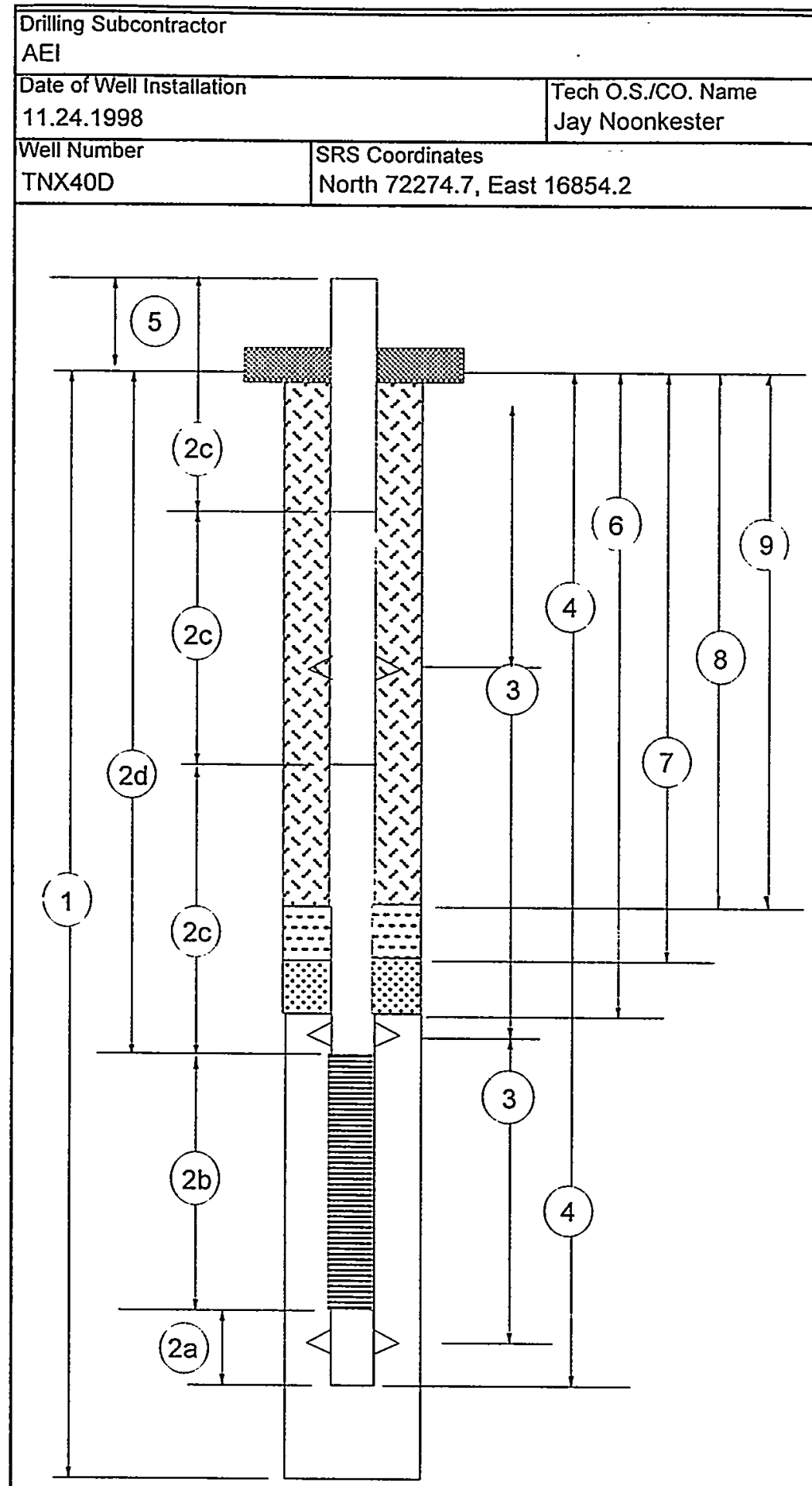

Note-All measurements are from ground surface at start of boring (measurements to nearest 0.1 foot).

1. Total Drilled Depth/Hole Diameter 14.3 feet $/ 47 / 8^{n}$

2. Casing/Screen Tally (Measured to Nearest 0.01 foot)

a) Sump and Plug Length 0.3 feet

b) Screen Length 10.0 feet

c) Casing Joint Lengths (Measured in Uphole Sequence from Top of Screen) one $5.0 \mathrm{ft}$ - 2" PVC feet

one $1.4 \mathrm{ft}$ - 2" PVC

d) Depth to Top of Screen 4.0 feet

3. Depths to Centralizers n.a.

4. Total Depth of Installed Well 14.3

5. Casing Stick Up (Standard 2.5' A.G.S.) 2.4 feet

6. Depth to Top of Filter Pack 2.0 foot

7. Depth to Top of Fine Sand Seal n.a.

8. Depth to Top of Bentonite Seal $\underline{0.0 \text { feet }}$

9. Thickness of Grout n.a.

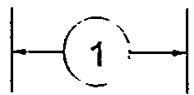


Appendix B

Field Data 


\begin{tabular}{|c|c|c|c|c|c|c|c|}
\hline \multicolumn{9}{|c|}{ Dec-98 } & \multicolumn{7}{c|}{ TNX PLUME WELLS } \\
\hline $\begin{array}{c}\text { WELL } \\
\text { NUMBER }\end{array}$ & DATE & $\begin{array}{c}\text { WATER } \\
\text { LEVEL }\end{array}$ & PH & $\begin{array}{c}\text { TEMP } \\
\text { (C) }\end{array}$ & $\begin{array}{c}\text { COND } \\
(\mathrm{mS} / \mathrm{cm})\end{array}$ & $\begin{array}{c}\text { DO } \\
(\mathrm{mg} / \mathrm{L})\end{array}$ & $\begin{array}{c}\text { Eh } \\
(\mathrm{mv})\end{array}$ \\
\hline \hline TGSC 2 & $12 / 9 / 98$ & 6.09 & 6.62 & 18.3 & 0.256 & 0.0 & -311 \\
\hline TCM 1 & na & na & na & na & na & na & na \\
\hline TCM 2 & $12 / 10 / 98$ & 6.32 & 4.99 & 19.2 & 0.154 & 1.4 & 509 \\
\hline TCM 3 & na & na & na & na & na & na & na \\
\hline TCM 4 & $12 / 11 / 98$ & 7.26 & 5.26 & 19.3 & 0.08 & 0.5 & 484 \\
\hline TCM 5 & $12 / 11 / 98$ & 4.40 & 5.4 & 19.2 & 0.136 & 1.4 & 352 \\
\hline TCM 6 & $12 / 11 / 98$ & 7.83 & 4.57 & 18.9 & 0.112 & 1.3 & 581 \\
\hline TCM 7 & $12 / 11 / 98$ & 7.63 & 4.97 & 19.1 & 0.121 & 1.3 & 517 \\
\hline TCM 8 & $12 / 11 / 98$ & 7.59 & 5.08 & 18.4 & 0.156 & 0.1 & 390 \\
\hline TIR 1U & $12 / 10 / 98$ & 9.18 & 4.36 & 19.1 & 0.134 & 3.6 & 566 \\
\hline TNX 8 & $12 / 10 / 98$ & 7.81 & 5.29 & 18.4 & 0.128 & 3.2 & 475 \\
\hline TNX 9 & $12 / 10 / 98$ & 9.41 & 4.91 & 18.8 & 0.144 & 0.6 & 432 \\
\hline TNX 10 & $12 / 10 / 98$ & 10.05 & 5.06 & 18.6 & 0.096 & 3.4 & 400 \\
\hline TNX 11 & $12 / 10 / 98$ & 7.86 & 4.84 & 19.91 & 0.037 & 1.3 & 339.6 \\
\hline TNX 12 & $12 / 10 / 98$ & 5.75 & 5.97 & 19.74 & 0.048 & 5.2 & 336 \\
\hline TNX 26 & na & na & na & na & na & na & na \\
\hline TNX 28 & $12 / 9 / 98$ & 8.86 & 5.12 & 20.22 & 0.032 & 0.9 & 375.4 \\
\hline TNX 29 & $12 / 9 / 98$ & 8.92 & 4.95 & 20.17 & 0.044 & 2.0 & 390.9 \\
\hline TNX 30 & $12 / 9 / 98$ & 10.32 & 4.54 & 19.6 & 0.11 & 1.8 & 323 \\
\hline TNX 31 & $12 / 9 / 98$ & 10.22 & 4.84 & 19.4 & 0.094 & 1.8 & 328 \\
\hline TNX 32 & $12 / 9 / 98$ & 8.44 & 5.05 & 19.3 & 0.113 & 2.3 & 328 \\
\hline TNX 33 & $12 / 9 / 98$ & 8.15 & 5.08 & 19.4 & 0.116 & 2.7 & 403 \\
\hline TNX 34 & $12 / 9 / 98$ & 7.40 & 5.05 & 19.5 & 0.077 & 1.9 & 388 \\
\hline TNX 35 & $12 / 9 / 98$ & 4.20 & 4.98 & 19.3 & 0.061 & 2.0 & 447 \\
\hline TNX 36 & $12 / 14 / 98$ & 7.09 & 5.31 & 18.5 & 0.072 & 0.1 & 473 \\
\hline TNX 37 & $12 / 14 / 98$ & 7.76 & 5.2 & 18.4 & 0.054 & 0.2 & 466 \\
\hline P 26 & na & na & na & na & na & na & na \\
\hline
\end{tabular}




\begin{tabular}{|c|c|c|c|c|c|c|c|}
\hline \multicolumn{3}{|c|}{ Jan-99 } & \multicolumn{4}{|c|}{ TNX PLUME WELLS } & \multirow[b]{2}{*}{$\begin{array}{c}\mathrm{Eh} \\
(\mathrm{mV})\end{array}$} \\
\hline $\begin{array}{c}\text { WELL } \\
\text { NUMBER }\end{array}$ & DATE & $\begin{array}{l}\text { WATER } \\
\text { LEVEL }\end{array}$ & $\overline{\mathrm{PH}}$ & $\begin{array}{c}\text { TEMP } \\
\text { (C) }\end{array}$ & $\begin{array}{c}\text { COND } \\
(\mathrm{mS} / \mathrm{cm})\end{array}$ & $\begin{array}{c}\text { DO } \\
(\mathrm{mg} / \mathrm{L}) .\end{array}$ & \\
\hline TGSC 2 & $1 / 19 / 99$ & 5.59 & 7.31 & 16.4 & 0.422 & 0.0 & -48 \\
\hline TCM 1 & na & na & na & na & na & na & na \\
\hline TCM 2 & $1 / 19 / 99$ & 5.65 & 5.11 & 16.7 & 0.158 & 0.8 & 513 \\
\hline TCM 3 & na & na & na & na & na & na & na \\
\hline TCM 4 & $1 / 19 / 99$ & 6.78 & 5.3 & 17.5 & 0.09 & 0.5 & 465 \\
\hline TCM 5 & $1 / 19 / 99$ & 6.88 & 5.65 & 16.4 & 0.172 & 0.8 & 425 \\
\hline TCM 6 & $1 / 19 / 99$ & 7.34 & 4.86 & 16.5 & 0.136 & 0.8 & 517 \\
\hline TCM 7 & $1 / 19 / 99$ & 7.12 & 5.08 & 16.7 & 0.216 & 1.1 & 457 \\
\hline TCM 8 & $1 / 19 / 99$ & 7.17 & 5.11 & 15.4 & 0.158 & 0.2 & 500 \\
\hline TIR 1U & $1 / 19 / 99$ & 8.68 & 4.49 & 17.3 & 0.13 & 2.9 & 598 \\
\hline TNX 8 & $1 / 19 / 99$ & 7.32 & 5.32 & 16.3 & 0.116 & 2.5 & 465 \\
\hline TNX 9 & $1 / 19 / 99$ & 8.88 & 4.94 & 17.7 & 0.146 & 0.7 & 462 \\
\hline TNX 10 & $1 / 19 / 99$ & 9.65 & 5.03 & 18.5 & 0.098 & 2.5 & 477 \\
\hline TNX 11 & $1 / 19 / 99$ & 7.33 & 5.12 & 19.2 & 0.046 & 0.8 & 457 \\
\hline $\begin{array}{ll}\text { TNX } 12 \\
\end{array}$ & $1 / 19 / 99$ & 5.17 & 6.06 & 17.8 & 0.062 & 0.6 & 391 \\
\hline TNX 26 & na & na & na & na & na & na & na \\
\hline TNX 28 & $1 / 18 / 99$ & 8.59 & 5.37 & 16.8 & 0.044 & 0.8 & 475 \\
\hline TNX 29 & $1 / 18 / 99$ & 8.69 & 5.15 & 16.6 & 0.06 & 1.7 & 504 \\
\hline TNX 30 & $1 / 18 / 99$ & 9.82 & 4.66 & 18.3 & 0.134 & 1.0 & 562 \\
\hline TNX 31 & $1 / 18 / 99$ & 10.20 & 5.01 & 17.3 & 0.116 & 2.4 & 502 \\
\hline $\begin{array}{lll}\text { TNX } 32 \\
\end{array}$ & $1 / 18 / 99$ & 8.08 & 5.17 & 17.5 & 0.142 & 3.0 & 499 \\
\hline TNX 33 & $1 / 18 / 99$ & 7.67 & 5.32 & 17.3 & 0.14 & 1.8 & 474 \\
\hline $\begin{array}{ll}\text { TNX } 34 \\
\end{array}$ & $1 / 18 / 99$ & 6.82 & 5.29 & 17.4 & 0.098 & 1.5 & 479 \\
\hline TNX 35 & $1 / 18 / 99$ & 6.65 & 5.44 & 17.3 & 0.078 & 2.1 & 463 \\
\hline TNX 36 & $1 / 18 / 99$ & 6.66 & 5.3 & 17 & 0.74 & 0.2 & 446 \\
\hline TNX 37 & $1 / 18 / 99$ & 7.18 & 5.19 & 17.3 & 0.052 & 0.2 & 442 \\
\hline $\mathrm{P} \quad 26$ & $1 / 19 / 99$ & 36.52 & 5.59 & 18.8 & 0.034 & 5.3 & 537 \\
\hline
\end{tabular}




\begin{tabular}{|c|c|c|c|c|c|c|c|}
\hline \multicolumn{7}{|c|}{ Mar-99 } \\
\hline $\begin{array}{c}\text { WELL } \\
\text { NUMBER }\end{array}$ & DATE & $\begin{array}{c}\text { WATER } \\
\text { LEVEL }\end{array}$ & PH & $\begin{array}{c}\text { TENIP } \\
\text { (C) }\end{array}$ & $\begin{array}{c}\text { COND } \\
(\mathrm{mS/cm})\end{array}$ & $\begin{array}{c}\text { DO } \\
(\mathrm{mg} / \mathrm{L})\end{array}$ & $\begin{array}{c}\text { RedoX } \\
\text { (mV) }\end{array}$ \\
\hline \hline TGSC 2 & $3 / 4 / 99$ & 5.51 & 10.08 & 16.9 & 0.414 & 0.0 & 3 \\
\hline TCM 1 & $3 / 5 / 99$ & 6.22 & 5.07 & 18.9 & 0.064 & 0.1 & 415 \\
\hline TCM 2 & $3 / 5 / 99$ & 5.53 & 5.22 & 16.2 & 0.158 & 0.7 & 496 \\
\hline TCM 3 & $3 / 5 / 99$ & 5.91 & 5.59 & 16.6 & 0.2 & 0.2 & 499 \\
\hline TCM 4 & $3 / 4 / 99$ & 6.69 & 5.17 & 17.8 & 0.072 & 0.9 & 481 \\
\hline TCM 5 & $3 / 4 / 99$ & 6.75 & 5.62 & 16.5 & 0.154 & 1.0 & 440 \\
\hline TCM 6 & $3 / 4 / 99$ & 7.21 & 4.63 & 16.9 & 0.118 & 1.2 & 548 \\
\hline TCM 7 & $3 / 4 / 99$ & 6.94 & 5.64 & 16.6 & 0.142 & 1.0 & 456 \\
\hline TCM 8 & $3 / 4 / 99$ & 7.04 & 5.12 & 15.7 & 0.186 & 0.1 & 492 \\
\hline TIR 1U & $3 / 4 / 99$ & 8.68 & 4.47 & 16.7 & 0.13 & 3.1 & 622 \\
\hline TNX 8 & $3 / 4 / 99$ & 6.91 & 5.39 & 15.5 & 0.108 & 2.8 & 466 \\
\hline TNX 9 & $3 / 4 / 99$ & 8.64 & 5.1 & 16.8 & 0.15 & 0.9 & 440 \\
\hline TNX 10 & $3 / 4 / 99$ & 9.41 & 5.09 & 17.6 & 0.09 & 3.1 & 531 \\
\hline TNX 11 & $3 / 1 / 99$ & 7.35 & 5.11 & 18.9 & 0.044 & 0.9 & 442 \\
\hline TNX 12 & $3 / 1 / 99$ & 5.25 & 6.05 & 17.1 & 0.06 & 0.7 & 382 \\
\hline TNX 26 & $3 / 2 / 99$ & 6.48 & 5.92 & 18.5 & 0.092 & 0.2 & 328 \\
\hline TNX 28 & $3 / 1 / 99$ & 8.59 & 5.42 & 16.6 & 0.044 & 1.4 & 483 \\
\hline TNX 29 & $3 / 1 / 99$ & 8.58 & 5.19 & 16.2 & 0.088 & 1.6 & 520 \\
\hline TNX 30 & $3 / 2 / 99$ & 9.61 & 4.77 & 17.7 & 0.122 & 1.7 & 570 \\
\hline TNX 31 & $3 / 2 / 99$ & 9.52 & 5.15 & 16.7 & 0.12 & 2.8 & 533 \\
\hline TNX 32 & $3 / 2 / 99$ & 7.77 & 5.39 & 16.6 & 0.128 & 3.5 & 500 \\
\hline TNX 33 & $3 / 2 / 99$ & 7.35 & 5.47 & 16.3 & 0.134 & 1.6 & 491 \\
\hline TNX 34 & $3 / 2 / 99$ & 6.54 & 5.38 & 16.4 & 0.092 & 2.2 & 481 \\
\hline TNX 35 & $3 / 2 / 99$ & 6.32 & 5.58 & 16.6 & 0.078 & 2.8 & 473 \\
\hline TNX 36 & $3 / 2 / 99$ & 6.22 & 5.38 & 16.4 & 0.074 & 0.3 & 480 \\
\hline TNX 37 & $3 / 2 / 99$ & 6.75 & 5.28 & 16.3 & 0.054 & 0.3 & 484 \\
\hline P 26 & na & na & na & na & na & na & na \\
\hline
\end{tabular}




\begin{tabular}{|c|c|c|c|}
\hline & \multicolumn{3}{|c|}{ Depth to Water (feet) } \\
Date & TNX 38D & TNX 39D & TNX 40D \\
\hline $1 / 13 / 99$ & 2.11 & 3.09 & 3.21 \\
$2 / 10 / 99$ & 2.72 & 5.17 & 10.05 \\
$3 / 16 / 99$ & 2.88 & 5.79 & 10.65 \\
$4 / 27 / 99$ & 4.74 & 6.42 & 16.36 \\
$5 / 18 / 99$ & 5.05 & 6.76 & 16.35 \\
\hline
\end{tabular}


Appendix C

Results from Analysis of Chlorinated Volatile Organic Compounds 


\begin{tabular}{|c|c|c|c|c|c|c|c|c|}
\hline \multirow[b]{2}{*}{ Well ID } & \multirow[b]{2}{*}{ Sample Date } & \multicolumn{6}{|c|}{ CVOCs (ug/L) } & \multirow[b]{2}{*}{ Sample Mod. } \\
\hline & & CDCE & $\mathrm{CHCl} 3$ & TCA & $\mathrm{CCl} 4$ & TCE & PCE & \\
\hline P26D & $1 / 19 / 99$ & nd & nd & nd & nd & nd & nd & \\
\hline TCM1 & $3 / 5 / 99$ & nd & nd & nd & nd & 6.1 & nd & \\
\hline TCM1 & $3 / 5 / 99$ & nd & nd & nd & nd & 6.2 & nd & $\mathrm{d}$ \\
\hline TCM2 & $12 / 10 / 98$ & nd & 1.5 & nd & 4.1 & 64.8 & 0.4 & \\
\hline TCM2 & $1 / 19 / 99$ & nd & 2.7 & nd & 5.3 & 96.3 & 0.6 & \\
\hline TCM2 & $3 / 5 / 99$ & nd & 2 & nd & 2.4 & 85.4 & 0.1 & \\
\hline TCM2 & $3 / 5 / 99$ & nd & 2.3 & nd & 2.8 & 92.4 & 0.6 & $\mathrm{~d}$ \\
\hline TCM3 & $3 / 5 / 99$ & nd & 1.6 & nd & 0.7 & 64 & 0.4 & \\
\hline TCM3 & $3 / 5 / 99$ & nd & 1.4 & nd & 0.6 & 59.9 & 0.4 & $\mathrm{~d}$ \\
\hline TCM4 & $12 / 11 / 98$ & nd & 0.5 & nd & 1.3 & 23.6 & 0.2 & \\
\hline TCM4 & $1 / 19 / 99$ & nd & 0.8 & nd & 1.1 & 25.8 & 0.2 & \\
\hline TCM4 & $3 / 4 / 99$ & nd & 0.5 & nd & 1.1 & 26.8 & 0.2 & \\
\hline TCM4 & $3 / 4 / 99$ & nd & 0.7 & nd & 1.2 & 29.5 & 0.2 & $\mathrm{~d}$ \\
\hline TCM5 & $12 / 10 / 98$ & nd & 0.8 & nd & 4.7 & 41.7 & 0.4 & \\
\hline TCM5 & $1 / 19 / 99$ & nd & 0.9 & nd & 2.2 & 45.9 & 0.3 & \\
\hline TCM5 & $3 / 4 / 99$ & nd & 0.9 & nd & 2.2 & 57.5 & 0.4 & \\
\hline TCM5 & $3 / 4 / 99$ & nd & 1 & nd & 1.9 & 54.5 & 0.4 & $\mathrm{~d}$ \\
\hline TCM6 & $12 / 11 / 98$ & nd & 0.9 & nd & 4.4 & 48.9 & 0.3 & \\
\hline TCM6 & $1 / 19 / 99$ & nd & 1.5 & nd & 3.2 & 54.8 & 0.4 & \\
\hline TCM6 & $3 / 4 / 99$ & nd & 1.4 & nd & 2.3 & 58.8 & 0.4 & \\
\hline TCM6 & $3 / 4 / 99$ & nd & 1.3 & nd & 2.2 & 58.5 & 0.4 & $\bar{d}$ \\
\hline TCM7 & $12 / 11 / 98$ & nd & 0.8 & nd & 4.2 & 41.1 & 0.3 & \\
\hline TCM7 & $1 / 19 / 99$ & nd & 0.9 & nd & 0.2 & 40.8 & 0.3 & \\
\hline TCM7 & $3 / 4 / 99$ & nd & 1.1 & nd & 1 & 47.9 & 0.3 & \\
\hline TCM7 & $3 / 4 / 99$ & nd & 1.3 & nd & 1.1 & 52.5 & 0.3 & d \\
\hline TCM8 & $12 / 11 / 98$ & nd & 1.5 & nd & 3 & 57.7 & 0.4 & \\
\hline TCM8 & $1 / 19 / 99$ & nd & 1.9 & nd & 2.7 & 62.7 & 0.5 & \\
\hline TCM8 & $3 / 4 / 99$ & nd & 2 & nd & 1.3 & 69.9 & 0.5 & \\
\hline TCM8 & $3 / 4 / 99$ & nd & 2.2 & nd & 1.6 & 75.7 & 0.6 & $\mathrm{~d}$ \\
\hline TGSC1 & $12 / 21 / 98$ & nd & nd & nd & nd & 0.3 & nd & \\
\hline TGSC2 & $12 / 9 / 98$ & nd & 0.5 & nd & 0.1 & 22.5 & 0.2 & \\
\hline TGSC2 & $12 / 9 / 98$ & nd & 0.5 & nd & 0.1 & 21 & 0.2 & d \\
\hline TGSC2 & $12 / 21 / 98$ & nd & 0.5 & nd & nd & 18.3 & 0.1 & 1 \\
\hline TGSC2 & $12 / 21 / 98$ & nd & nd & nd & nd & 17.9 & 0.3 & 2 \\
\hline TGSC2 & $12 / 21 / 98$ & nd & nd & nd & 0.1 & 19.6 & 0.2 & 3 \\
\hline TGSC2 & $12 / 21 / 98$ & nd & nd & nd & 0.1 & 18.9 & 0.2 & 4 \\
\hline TGSC2 & $12 / 21 / 98$ & nd & nd & nd & 0.1 & 15.6 & 0.1 & 5 \\
\hline TGSC2 & $12 / 21 / 98$ & nd & nd & nd & 0.1 & 15.8 & 0.1 & 6 \\
\hline TGSC2 & $12 / 21 / 98$ & nd & nd & nd & 0.1 & 14.7 & 0.1 & 7 \\
\hline TGSC2 & $1 / 19 / 99$ & nd & nd & nd & nd & 7.6 & 0.1 & \\
\hline TGSC2 & $3 / 4 / 99$ & nd & nd & nd & nd & 2.4 & 0.1 & \\
\hline TGSC2 & $3 / 4 / 99$ & nd & nd & nd & nd & 2.4 & nd & d \\
\hline TIR1U & $12 / 10 / 98$ & nd & 0.6 & nd & 4.7 & 33.9 & 0.2 & \\
\hline TIR1U & 1/19/99 & nd & 0.8 & nd & 1.6 & 31.2 & 0.2 & \\
\hline TIR1U & $3 / 4 / 99$ & nd & 1 & nd & 1.2 & 41.8 & 0.2 & \\
\hline
\end{tabular}




\begin{tabular}{|c|c|c|c|c|c|c|c|c|}
\hline \multirow[b]{2}{*}{ Well ID } & \multirow[b]{2}{*}{ Sample Date } & \multicolumn{6}{|c|}{ CVOCs (ug/L) } & \multirow[b]{2}{*}{ Sample Mod. } \\
\hline & & CDCE & $\mathrm{CHCl} 3$ & TCA & $\mathrm{CCl} 4$ & TCE & PCE & \\
\hline TIR1U & $3 / 4 / 99$ & nd & 1 & nd & 1.2 & 41.5 & 0.2 & $\bar{d}$ \\
\hline TNX10D & $12 / 10 / 98$ & nd & 0.4 & nd & 0.2 & 9.1 & 0.1 & \\
\hline TNX10D & $1 / 19 / 99$ & nd & 0.5 & nd & 0.1 & 9.2 & nd & \\
\hline TNX10D & $3 / 4 / 99$ & nd & 0.9 & nd & 0.1 & 17.8 & nd & \\
\hline TNX10D & $3 / 4 / 99$ & nd & 0.8 & nd & 0.13 & 17.1 & nd & $\bar{d}$ \\
\hline TNX11D & $12 / 10 / 98$ & nd & nd & nd & nd & 2.4 & 0.2 & \\
\hline TNX11D & $1 / 19 / 99$ & nd & nd & nd & nd & 2.4 & nd & \\
\hline TNX11D & $3 / 1 / 99$ & nd & nd & nd & nd & 3.6 & nd & \\
\hline TNX11D & $3 / 1 / 99$ & nd & nd & nd & nd & 3.9 & nd & d \\
\hline TNX12D & $12 / 10 / 98$ & nd & nd & nd & nd & nd & 0.3 & \\
\hline TNX12D & $1 / 19 / 99$ & nd & nd & nd & nd & 0.4 & nd & \\
\hline TNX12D & $3 / 1 / 99$ & nd & nd & nd & nd & 0.3 & nd & \\
\hline TNX12D & $3 / 1 / 99$ & nd & nd & nd & nd & 0.3 & nd & d \\
\hline TNX26 & $3 / 1 / 99$ & nd & nd & nd & nd & 0.9 & nd & \\
\hline TNX26 & $3 / 1 / 99$ & nd & nd & nd & nd & 1 & nd & d \\
\hline TNX28 & $12 / 9 / 98$ & nd & nd & nd & 0.1 & 2.8 & 0.2 & \\
\hline TNX28 & $1 / 18 / 99$ & nd & nd & nd & nd & 3.7 & nd & \\
\hline TNX28 & $3 / 1 / 99$ & nd & nd & nd & 0.1 & 3.6 & nd & \\
\hline TNX28 & $3 / 1 / 99$ & nd & nd & nd & 0.1 & 3.9 & nd & $\bar{d}$ \\
\hline TNX29 & $12 / 9 / 98$ & nd & nd & nd & 3.4 & 21.2 & 0.4 & \\
\hline$T N \times 29$ & $1 / 18 / 99$ & nd & nd & nd & 1.5 & 24.5 & 0.2 & \\
\hline TNX29 & $3 / 1 / 99$ & nd & 0.9 & nd & 2.2 & 43.3 & 0.4 & \\
\hline TNX29 & $3 / 1 / 99$ & nd & 0.9 & nd & 2.4 & 46.3 & 0.5 & $\bar{d}$ \\
\hline TNX30 & $12 / 9 / 98$ & nd & 0.6 & nd & 0.5 & 23.1 & 0.4 & \\
\hline TNX30 & $1 / 18 / 99$ & nd & 1.1 & nd & 0.5 & 28.9 & 0.1 & \\
\hline TNX30 & $3 / 2 / 99$ & nd & 1.1 & nd & 0.4 & 29.6 & 0.1 & \\
\hline TNX30 & $3 / 2 / 99$ & nd & 1.3 & nd & 0.4 & 32.8 & 0.1 & $\mathrm{~d}$ \\
\hline TNX31 & $12 / 9 / 98$ & nd & 0.7 & nd & 0.1 & 12.2 & 0.3 & \\
\hline TNX31 & $1 / 18 / 99$ & nd & 1 & nd & 0.1 & 9.4 & nd & \\
\hline TNX31 & $3 / 2 / 99$ & nd & 1.7 & nd & 0.1 & 15.7 & nd & \\
\hline TNX31 & $3 / 2 / 99$ & nd & 1.7 & nd & 0.1 & 17.2 & nd & d \\
\hline TNX32 & $12 / 9 / 98$ & nd & 0.9 & nd & nd & 11.7 & 0.2 & \\
\hline TNX32 & $1 / 18 / 99$ & nd & 1.2 & nd & nd & 8.2 & nd & \\
\hline TNX32 & $3 / 2 / 99$ & nd & 1.4 & nd & nd & 3.1 & nd & \\
\hline TNX32 & $3 / 2 / 99$ & nd & 1.4 & nd & nd & 2.9 & nd & $d$ \\
\hline TNX33 & $12 / 9 / 98$ & nd & 0.8 & nd & nd & 2.8 & 0.1 & \\
\hline TNX33 & $1 / 18 / 99$ & nd & 0.9 & nd & nd & 8.1 & nd & \\
\hline TNX33 & $3 / 2 / 99$ & nd & 0.9 & nd & nd & 17.3 & nd & \\
\hline TNX33 & $3 / 2 / 99$ & nd & 0.8 & nd & nd & 16.1 & nd & d \\
\hline TNX34 & $12 / 9 / 98$ & nd & nd & nd & nd & 0.5 & 0.1 & \\
\hline TNX34 & $1 / 18 / 99$ & nd & 0.5 & nd & nd & 0.6 & nd & \\
\hline TNX34 & $3 / 2 / 99$ & nd & 0.5 & nd & nd & 2.4 & nd & \\
\hline TNX34 & $3 / 2 / 99$ & nd & 0.7 & nd & nd & 2.4 & nd & d \\
\hline TNX35 & $12 / 9 / 98$ & nd & nd & nd & nd & 0.5 & 0.1 & \\
\hline TNX35 & $1 / 18 / 99$ & nd & nd & nd & nd & 0.4 & nd & \\
\hline
\end{tabular}


all data

\begin{tabular}{|l|c|c|c|c|c|c|c|c|}
\hline & & \multicolumn{9}{|c|}{ CVOCs (ug/L) } & \multirow{2}{*}{} \\
\cline { 3 - 9 } Well ID & Sample Date & CDCE & CHCl3 & TCA & CCl4 & TCE & PCE & Sample Mod. \\
\hline TNX35 & $3 / 2 / 99$ & nd & nd & nd & nd & 0.8 & nd & \\
\hline TNX35 & $3 / 2 / 99$ & nd & nd & nd & nd & 0.7 & nd & $\mathrm{d}$ \\
\hline TNX36 & $12 / 14 / 98$ & nd & nd & nd & nd & 1.3 & nd & \\
\hline TNX36 & $1 / 18 / 99$ & nd & nd & nd & nd & 1.7 & nd & \\
\hline TNX36 & $3 / 2 / 99$ & nd & nd & nd & nd & 1.7 & nd & \\
\hline TNX36 & $3 / 2 / 99$ & nd & nd & nd & nd & 1.5 & nd & $\mathrm{d}$ \\
\hline TNX37 & $12 / 14 / 98$ & nd & nd & nd & nd & 0.6 & nd & \\
\hline TNX37 & $1 / 18 / 99$ & nd & nd & nd & nd & 0.6 & nd & \\
\hline TNX37 & $3 / 2 / 99$ & nd & nd & nd & nd & 0.6 & nd & d \\
\hline TNX8D & $12 / 10 / 98$ & nd & 0.5 & nd & nd & 2.1 & nd & \\
\hline TNX8D & $1 / 19 / 99$ & nd & 0.7 & nd & nd & 3.4 & nd & \\
\hline TNX8D & $3 / 4 / 99$ & nd & 0.8 & nd & nd & 4 & nd & \\
\hline TNX8D & $3 / 4 / 99$ & nd & 0.8 & nd & nd & 4 & nd & \\
\hline TNX9D & $12 / 10 / 98$ & nd & nd & nd & nd & 0.3 & nd & \\
\hline TNX9D & $1 / 19 / 99$ & nd & nd & nd & nd & 0.5 & nd & \\
\hline TNX9D & $3 / 4 / 99$ & nd & 0.9 & nd & nd & 0.9 & nd & \\
\hline TNX9D & $3 / 4 / 99$ & nd & 0.8 & nd & nd & 0.9 & nd & $\mathrm{d}$ \\
\hline
\end{tabular}

